\title{
Atmospheric impact of the 1783-1784 Laki eruption: Part I Chemistry modelling
}

\author{
D. S. Stevenson ${ }^{1}$, C. E. Johnson ${ }^{2}$, E. J. Highwood ${ }^{3}$, V. Gauci ${ }^{4}$, W. J. Collins ${ }^{2}$, and R. G. Derwent ${ }^{2}$ \\ ${ }^{1}$ Institute for Meteorology, University of Edinburgh, Edinburgh, UK \\ ${ }^{2}$ Met Office, Bracknell, UK \\ ${ }^{3}$ Department of Meteorology, University of Reading, UK \\ ${ }^{4}$ Department of Earth Sciences, The Open University, UK
}

Received: 29 November 2002 - Published in Atmos. Chem. Phys. Discuss.: 6 February 2003

Revised: 25 April 2003 - Accepted: 6 May 2003 - Published: 19 May 2003

\begin{abstract}
Results from the first chemistry-transport model study of the impact of the 1783-1784 Laki fissure eruption (Iceland: $64^{\circ} \mathrm{N}, 17^{\circ} \mathrm{W}$ ) upon atmospheric composition are presented. The eruption released an estimated $61 \mathrm{Tg}(\mathrm{S})$ as $\mathrm{SO}_{2}$ into the troposphere and lower stratosphere. The model has a high resolution tropopause region, and detailed sulphur chemistry. The simulated $\mathrm{SO}_{2}$ plume spreads over much of the Northern Hemisphere, polewards of $\sim 40^{\circ} \mathrm{N}$. About $70 \%$ of the $\mathrm{SO}_{2}$ gas is directly deposited to the surface before it can be oxidised to sulphuric acid aerosol. The main $\mathrm{SO}_{2}$ oxidants, $\mathrm{OH}$ and $\mathrm{H}_{2} \mathrm{O}_{2}$, are depleted by up to $40 \%$ zonally, and the lifetime of $\mathrm{SO}_{2}$ consequently increases. Zonally averaged tropospheric $\mathrm{SO}_{2}$ concentrations over the first three months of the eruption exceed $20 \mathrm{ppbv}$, and sulphuric acid aerosol reaches $\sim 2 \mathrm{ppbv}$. These compare to modelled preindustrial/present-day values of $0.1 / 0.5 \mathrm{ppbv} \mathrm{SO}_{2}$ and $0.1 / 1.0$ ppbv sulphate. A total sulphuric acid aerosol yield of 17-22 $\operatorname{Tg}(\mathrm{S})$ is produced. The mean aerosol lifetime is 6-10 days, and the peak aerosol loading of the atmosphere is 1.4-1.7 $\operatorname{Tg}(\mathrm{S})$ (equivalent to 5.9-7.1 Tg of hydrated sulphuric acid aerosol). These compare to modelled pre-industrial/presentday sulphate burdens of $0.28 / 0.81 \mathrm{Tg}(\mathrm{S})$, and lifetimes of $6 / 5$ days, respectively. Due to the relatively short atmospheric residence times of both $\mathrm{SO}_{2}$ and sulphate, the aerosol loading approximately mirrors the temporal evolution of emissions associated with the eruption. The model produces a reasonable simulation of the acid deposition found in Greenland ice cores. These results appear to be relatively insensitive to the vertical profile of emissions assumed, although if more of the emissions reached higher levels $(>12 \mathrm{~km})$, this would give longer lifetimes and larger aerosol yields. Introducing the emissions in episodes generates similar results to using monthly mean emissions, because the atmospheric lifetimes are similar to the repose periods between episodes. Most previous estimates of the global aerosol loading associated with
\end{abstract}

Correspondence to: D. S. Stevenson (davids@met.ed.ac.uk)
Laki did not use atmospheric models; this study suggests that these earlier estimates have been generally too large in magnitude, and too long-lived. Environmental effects following the Laki eruption may have been dominated by the widespread deposition of $\mathrm{SO}_{2}$ gas rather than sulphuric acid aerosol.

\section{Introduction}

Large explosive volcanic eruptions of the past have significantly influenced Earth's climate (Robock, 2000). The crucial factor in determining the climate impact is not necessarily the magnitude of the eruption, but is thought to be the quantity of sulphur dioxide $\left(\mathrm{SO}_{2}\right)$ injected into the stratosphere. Oxidation of the $\mathrm{SO}_{2}$ generates sulphuric acid aerosol, which can persist for typically 1-2 years in the midstratosphere, and spread to cover much of the globe, as observed following the June 1991 Mt. Pinatubo eruption (Minnis et al., 1993). Stratospheric volcanic aerosol perturbs the planetary energy budget by reflecting sunlight, radiatively warming the aerosol layer, and cooling the underlying atmosphere, potentially affecting climate. Radiative perturbations can also generate significant dynamical feedbacks that may affect climate (Robock and Mao, 1992).

Eruptions that are mainly restricted to the troposphere are much less likely to alter climate, for two main reasons. Firstly, the $\mathrm{SO}_{2}$ will not all be oxidised to aerosol, as gas deposition processes operate on similar timescales to oxidation. Secondly, the aerosol generated will be efficiently removed by deposition processes, and it will have a tropospheric lifetime of only days to weeks, compared with months to years in the stratosphere. However, if the volcanic $\mathrm{SO}_{2}$ source is long-lived and sufficiently large, and if the emissions are efficiently oxidised to aerosol, then they also have the potential to significantly perturb the Earth's radiation budget and 
climate, in just the same way as present day anthropogenic $\mathrm{SO}_{2}$ emissions (Penner et al., 2001).

In June 1783, a major Icelandic fissure eruption began, at a volcano that has subsequently become known as Laki. The eruption had several eyewitnesses, and was recorded in detail by Steingrimsson (1998). A recent review by Thordarson and Self (2003) gives a detailed description of the eruption. Over eight months, an estimated $15 \mathrm{~km}^{3}$ of basaltic magma and 61 $\operatorname{Tg}(\mathrm{S})$ were emitted as $\mathrm{SO}_{2}$, with about $60 \%$ of this released during the first six weeks of the eruption (Thordarson et al., 1996). The eruption involved fire-fountaining of magma to an altitude up to $1.4 \mathrm{~km}$, and this was topped by an ash cloud reaching to a maximum height of between 9 and $13 \mathrm{~km}$, or around tropopause levels ( $\sim 10 \mathrm{~km}$ over Iceland in summer). The eruption was one of the largest individual tropospheric pollution events of the last 250 years, and the quantity of $\mathrm{SO}_{2}$ released was comparable to the total annual present-day anthropogenic input to the atmosphere: $71 \mathrm{Tg}(\mathrm{S})$ as $\mathrm{SO}_{2}$ in 1990 (Olivier et al., 1996). A dry fog, or aerosol haze at both ground level and altitude, was recorded over much of Europe during the second half of the year (Stothers, 1996; Grattan and Pyatt, 1999), and similar phenomena were observed in Canada and China (Demaree et al., 1998), suggesting that a hemispheric-scale tropospheric sulphate aerosol cloud formed.

Ice-cores record large volcanic eruptions as acidic layers; the amount of acid deposited is used as a proxy for the aerosol loading caused by the eruption, and hence the likely climate impact (Robertson et al., 2001). Several studies of Greenland ice-cores have found evidence of the Laki eruption, in the form of an ash layer and a peak in sulphate (Clausen and Hammer, 1988; Fiacco et al., 1994; Zielinski, 1995; Clausen et al., 1997). Laj et al. (1990) found a depletion of hydrogen peroxide $\left(\mathrm{H}_{2} \mathrm{O}_{2}\right)$ coincident with this sulphate peak. Fiacco et al. (1994) dated the ash layer from Laki as 1783 , with the sulphate peak arriving a year later, indicating that the sulphate had remained airborne for about a year, implying a significant stratospheric aerosol layer formed. More recent Greenland ice-core studies (Clausen et al., 1997; Mosley-Thompson et al., 2002), however, place the sulphate peak in 1783, and indicate a much shorter lived, mainly tropospheric aerosol layer existed. The proximity of Greenland to Iceland raises the possibility that Icelandic eruptions may be more frequently recorded in the ice core record, and their magnitudes overestimated with respect to more distal eruptions (Zielinski, 1995). In particular, major Icelandic eruptions restricted to the troposphere may deposit large amounts of acid to Greenland, without necessarily generating a largescale climate impact.

Previous assessments of the aerosol generated by Laki (Thordarson et al., 1996; Stothers, 1996; Thordarson and Self, 2003) have not employed atmospheric models, and have assumed that all of the $\mathrm{SO}_{2}$ released was converted to sulphuric acid aerosol. Thordarson et al. (1996) suggested that $>75 \%$ of the emissions were injected at around tropopause levels, and that the aerosol generated remained aloft at these levels for over a year.

In this work, the impact on atmospheric composition resulting from the Laki eruption has been simulated for the first time using a global 3-D chemistry-transport model (CTM). The CTM includes relatively detailed descriptions of gasphase and aqueous-phase sulphur and oxidant chemistry, deposition processes, and has a well resolved tropopause region; its main weaknesses are the relatively coarse horizontal resolution $\left(5^{\circ}\right)$, and the lack of any aerosol microphysics. The CTM simulates the formation, spread, and deposition of the aerosol, and the associated depletions of the oxidants $\left(\mathrm{H}_{2} \mathrm{O}_{2}, \mathrm{OH}\right.$, and $\left.\mathrm{O}_{3}\right)$ that convert gaseous and dissolved $\mathrm{SO}_{2}$ to sulphate. Other simulations of the model, for 1990 conditions and for pre-industrial conditions, provide baseline distributions of species to allow comparison of the model with recent observations and other models. Acid deposition to Greenland is simulated by the model, and is compared with ice-core records. The sulphate aerosol fields have been used in a complementary study (Highwood and Stevenson, 2003) to calculate radiative forcings and assess the climatic impact of the Laki eruption. This study finds that the simulated climate impact is broadly consistent with the observed climate anomalies, and gives further support to the modelled aerosol distributions.

\section{Chemistry-transport model}

We used a new version of the UK Met Office 3-D Lagrangian CTM STOCHEM (Collins et al., 1997, 1999, 2000), developed at the University of Edinburgh (STOCHEM-Ed). The main improvements over previous versions are increased vertical resolution in both the driving general circulation model (GCM) and the CTM, particularly around the tropopause. STOCHEM-Ed is closely coupled to the Unified Model (UM) GCM (Johns et al., 1997), directly receiving meteorological fields every $3 \mathrm{~h}$ (Johnson et al., 2001). The UM was configured as an atmosphere-only GCM with a resolution of $3.75^{\circ}$ longitude by $2.5^{\circ}$ latitude, with 58 vertical levels between the surface and $0.1 \mathrm{hPa}$. Recent climatologies of sea-surface temperatures and stratospheric ozone were used.

Several aspects of STOCHEM have been compared with observations, including transport and mixing on short timescales (Stevenson et al., 1998a) and long timescales (Collins et al., 1998), and the magnitudes, distributions and seasonal variations of nitrogen oxides $\left(\mathrm{NO}_{\mathrm{x}}\right)$, hydroxyl $(\mathrm{OH})$ and peroxy $\left(\mathrm{HO}_{2}\right)$ radicals (Collins et al., 1999), carbon monoxide (CO) (Kanakidou et al., 1999a), ozone $\left(\mathrm{O}_{3}\right)$ (Kanakidou et al., 1999b), and aerosol species (Derwent et al., 2003). The model has also taken part in several intercomparisons regarding transport and chemistry (Olson et al., 1997; Isaksen et al., 1999; Rasch et al., 2000; Prather et al., 2001). In all these studies, STOCHEM typically performed well within the range of other current models. This published 
validation work uses older model versions compared to the one used here, but several features of the new model version have been tested in similar ways, and generally performed well, albeit this work has not yet been published.

\subsection{Transport and mixing}

STOCHEM-Ed uses a Lagrangian transport scheme, dividing the atmosphere into 50000 equal mass air parcels. These parcels are advected by winds from the GCM with a 4th order Runge-Kutta algorithm, using linear horizontal interpolation and cubic vertical interpolation, and adding a small random walk component to simulate turbulent diffusive mixing. The parcels maintain an approximately even global distribution with time. Convective mixing is implemented by fully mixing a fraction of the parcels beneath a convective cloud top. The precipitation rate and fractional cloud cover determine the fraction mixed; this fraction has been tuned using observations of ${ }^{222} \mathrm{Rn}$ (e.g., Stevenson et al. (1998a)). Interparcel mixing occurs between parcels occupying the same grid-box after each 1-h advection step. The grid used for mixing is $5^{\circ}$ by $5^{\circ}$, with 22 vertical hybrid $(\eta)$ levels (6 levels with $\Delta \eta=0.1$ between $\eta=1.0$ and $\eta=0.4,15$ levels with $\Delta \eta=0.025$ between $\eta=0.4$ and $\eta=0.025$, and a top level between $\eta=0.025$ and $\eta=0.0003$ ). Hybrid co-ordinates are explained further in Collins et al. (1997), but can be considered as approximately equal to pressure divided by surface pressure. STOCHEM-Ed therefore has a vertical resolution of about $25 \mathrm{hPa}(600 \mathrm{~m})$ around the tropopause. The same grid is used for data output, and 3-D emission fields, such as lightning $\mathrm{NO}_{\mathrm{x}}$ and volcanic $\mathrm{SO}_{2}$.

\subsection{Chemical mechanism}

Seventy chemical species are simulated, with a comprehensive description of tropospheric chemistry. Within each air parcel, these chemical species take part in 174 photochemical, gas-phase, and aqueous-phase chemical reactions, describing the chemistry of methane $\left(\mathrm{CH}_{4}\right), \mathrm{CO}, \mathrm{NO}_{\mathrm{x}}, \mathrm{O}_{3}$, and 11 non-methane hydrocarbons (NMHC) (Collins et al., 1997, 1999). The scheme allows detailed calculation of diurnal and seasonal variations of oxidants, which are crucial to the sulphur chemistry.

The chemical mechanism also has a detailed description of several sulphur compounds, including dimethyl sulphide (DMS) oxidation (Jenkin et al., 1996) and aqueous-phase reactions. The main sulphur reactions and equilibria included are shown in Table 1. In the gas phase, reaction of $\mathrm{SO}_{2}$ with $\mathrm{OH}$ is the main oxidation pathway. An important natural source of $\mathrm{SO}_{2}$ and sulphuric acid aerosol (SA) is gas-phase oxidation of DMS by $\mathrm{OH}$ in sunlight, and by the nitrate radical $\left(\mathrm{NO}_{3}\right)$ in darkness. Oceanic plankton are the main source of DMS, but there are also some emissions from soils.

Aqueous-phase oxidation of $\mathrm{SO}_{2}$ is a major route for sulphate aerosol production (Langner and Rodhe, 1991). Dy- namic and convective cloud distributions are generated by the driving GCM, and passed to the CTM every 3 hours. Aqueous-phase chemistry is switched on within clouds. The model treats the aqueous-phase chemistry of several soluble species, including $\mathrm{SO}_{2}$, ammonia $\left(\mathrm{NH}_{3}\right)$, nitric acid $\left(\mathrm{HNO}_{3}\right)$, $\mathrm{H}_{2} \mathrm{O}_{2}$ and $\mathrm{O}_{3}$. In the presence of cloud water drops, gases are partitioned between gaseous and aqueous phases according to their Henry's Law coefficients. Compounds dissociate into their constituent ions in water. These two processes are rapid (Adams et al., 1999), and equilibrium is assumed. Reactions of $\mathrm{HSO}_{3}^{-}$and $\mathrm{SO}_{3}^{2-}$ with dissolved $\mathrm{H}_{2} \mathrm{O}_{2}$ and $\mathrm{O}_{3}$ to form sulphate $\left(\mathrm{SO}_{4}^{2-}\right)$ are significant $\mathrm{SO}_{2}$ oxidation pathways. Any ammonium ions $\left(\mathrm{NH}_{4}^{+}\right)$present combine with $\mathrm{SO}_{4}^{2-}$ ions to form ammonium sulphate aerosol $\left(\left(\mathrm{NH}_{4}\right)_{2} \mathrm{SO}_{4}\right)$. The remaining sulphate ions form sulphuric acid aerosol. After each 5-min chemical timestep, aqueous and gas phase concentrations re-equilibrate. Modelled aerosol distributions do not influence the photolysis rates. The model includes no aerosol microphysics; nucleation, coagulation and condensation processes are assumed to occur rapidly. Gas-phase sulphuric acid is therefore assumed to convert instantaneously to the equivalent mass of accumulation mode aerosol.

One change to the chemistry in this model version is implementation of the conversion of dinitrogen pentoxide $\left(\mathrm{N}_{2} \mathrm{O}_{5}\right)$ to nitrate aerosol (NAER) on sulphuric acid aerosol:

$\mathrm{N}_{2} \mathrm{O}_{5} \stackrel{\text { SA }}{\longrightarrow}$ 2NAER

where the current model SA concentration field is used to calculate the rate constant $\left(\mathrm{k}_{1}=5.0 \times 10^{-14}[\mathrm{SA}]\right)$, in a similar way to Dentener and Crutzen (1993). This inherently assumes a globally fixed aerosol size distribution and surface area. Previously, a fixed global rate constant was used for this reaction. Using the SA distribution to weight the reaction tends to reduce $\mathrm{NO}_{\mathrm{x}}$ concentrations, particularly in polluted areas.

\subsection{Emissions}

Surface trace gas emissions are added to air parcels within the (GCM derived) boundary layer above their sources. Gridded emission distributions with a horizontal resolution of $5^{\circ}$ $\times 5^{\circ}$ are used. When several air parcels occupy the boundary layer for the grid square, emissions are divided equally between them. If no air parcels are present, for example when the boundary layer is very shallow, emissions are stored until the next time-step, ensuring mass conservation.

Global annual emissions totals for various categories and gases are shown in Table 2. These values are for the 1990 scenario, but all the natural emissions (except volcanic $\mathrm{SO}_{2}$ in the Laki scenarios) remain constant in all of the experiments. In the 1860 and Laki scenarios, anthropogenic emissions are set to zero, and biomass burning totals are reduced to $20 \%$ of their 1990 values (Stevenson et al., 1998b; 
Table 1. Sulphur chemistry: Gas- and aqueous-phase reactions, equilibria and Henry's Law coefficients. [M] is the molecular density of air (molecules $\left.\mathrm{cm}^{-3}\right),\left[\mathrm{H}^{+}\right]$is the hydrogen ion concentration $\left(\mathrm{moll}^{-1}\right), T$ is temperature $(\mathrm{K}), T^{*}=1 / T-1 / 298$

\begin{tabular}{|c|c|}
\hline Gas-phase reactions & Rate constants $^{a}$ \\
\hline $\mathrm{SO}_{2}+\mathrm{OH}+\mathrm{M} \rightarrow \mathrm{H}_{2} \mathrm{SO}_{4}+\mathrm{HO}_{2}$ & $\operatorname{complex}^{e}: \mathrm{A} 6(\mathrm{~A} 3)^{(1 / A 7)}$ \\
\hline $\mathrm{DMS}+\mathrm{OH} \rightarrow \mathrm{CH}_{3} \mathrm{SO}+\mathrm{HCHO}$ & $9.6 \times 10^{-12} \exp (-234 / T)$ \\
\hline $\mathrm{DMS}+\mathrm{OH} \rightarrow \mathrm{DMSO}+\mathrm{HO}_{2}$ & complex $^{f}$ \\
\hline $\mathrm{DMS}+\mathrm{NO}_{3} \rightarrow \mathrm{CH}_{3} \mathrm{SO}+\mathrm{HCHO}+\mathrm{HNO}_{3}$ & $1.9 \times 10^{-13} \exp (520 / T)$ \\
\hline $\mathrm{CH}_{3} \mathrm{SO}+\mathrm{O}_{3} \rightarrow \mathrm{CH}_{3} \mathrm{SO}_{2}+\mathrm{O}_{2}$ & $6.0 \times 10^{-13}$ \\
\hline $\mathrm{CH}_{3} \mathrm{SO}+\mathrm{NO}_{2} \rightarrow \mathrm{CH}_{3} \mathrm{SO}_{2}+\mathrm{NO}$ & $8.0 \times 10^{-12}$ \\
\hline $\mathrm{CH}_{3} \mathrm{SO}_{2}+\mathrm{O}_{3} \rightarrow \mathrm{CH}_{3} \mathrm{SO}_{3}+\mathrm{O}_{2}$ & $3.0 \times 10^{-13}$ \\
\hline $\mathrm{CH}_{3} \mathrm{SO}_{2}+\mathrm{NO}_{2} \rightarrow \mathrm{CH}_{3} \mathrm{SO}_{3}+\mathrm{NO}$ & $4.0 \times 10^{-12}$ \\
\hline $\mathrm{CH}_{3} \mathrm{SO}_{2}+\mathrm{O}_{2} \rightarrow \mathrm{CH}_{3} \mathrm{O}_{2}+\mathrm{SO}_{2}$ & $5.0 \times 10^{13} \exp (-(1.0+(8656 / T)))$ \\
\hline $\mathrm{CH}_{3} \mathrm{SO}_{3}+\mathrm{HO}_{2} \rightarrow \mathrm{MSA}$ & $5.0 \times 10^{-11}$ \\
\hline $\mathrm{CH}_{3} \mathrm{SO}_{3}+\mathrm{O}_{2} \rightarrow \mathrm{CH}_{3} \mathrm{O}_{2}+\mathrm{SA}$ & $5.0 \times 10^{13} \exp (-(1.0+(11071 / T)))$ \\
\hline $\mathrm{CH}_{3} \mathrm{SO}_{3}+\mathrm{HCHO} \rightarrow \mathrm{MSA}+\mathrm{CO}+\mathrm{HO}_{2}$ & $1.6 \times 10^{-15}$ \\
\hline $\mathrm{DMSO}+\mathrm{OH} \rightarrow \mathrm{DMSO}_{2}+\mathrm{HO}_{2}$ & $5.8 \times 10^{-11}$ \\
\hline $\mathrm{DMSO}_{2}+\mathrm{OH} \rightarrow \mathrm{CH}_{3} \mathrm{SO}_{2} \mathrm{CH}_{2} \mathrm{O}_{2}$ & $1.0 \times 10^{-12}$ \\
\hline $\mathrm{CH}_{3} \mathrm{SO}_{2} \mathrm{CH}_{2} \mathrm{O}_{2}+\mathrm{NO} \rightarrow \mathrm{NO}_{2}+\mathrm{HCHO}+\mathrm{CH}_{3} \mathrm{SO}_{2}$ & $4.1 \times 10^{-12} \exp (180 / T)$ \\
\hline $\mathrm{CH}_{3} \mathrm{SO}_{2} \mathrm{CH}_{2} \mathrm{O}_{2}+\mathrm{CH}_{3} \mathrm{O}_{2} \rightarrow \mathrm{HO}_{2}+2 \mathrm{HCHO}+\mathrm{CH}_{3} \mathrm{SO}_{2}$ & $3.0 \times 10^{-13}$ \\
\hline Species & Henry's Law coefficients ${ }^{b}$ \\
\hline $\mathrm{SO}_{2}$ & $1.23 \times 10^{0} \exp \left(3120 T^{*}\right)$ \\
\hline $\mathrm{O}_{3}$ & $1.1 \times 10^{-2} \exp \left(2300 T^{*}\right)$ \\
\hline $\mathrm{HNO}_{3}$ & $3.3 \times 10^{6} \exp \left(8700 T^{*}\right)$ \\
\hline $\mathrm{H}_{2} \mathrm{O}_{2}$ & $7.36 \times 10^{4} \exp \left(6621 T^{*}\right)$ \\
\hline $\mathrm{NH}_{3}$ & $7.5 \times 10^{1} \exp \left(3400 T^{*}\right)$ \\
\hline $\mathrm{CO}_{2}$ & $3.4 \times 10^{-2} \exp \left(2420 T^{*}\right)$ \\
\hline
\end{tabular}

\begin{tabular}{|c|c|}
\hline Aqueous-phase equilibria & Equilibrium constants ${ }^{c}$ \\
\hline $\mathrm{SO}_{2}+\mathrm{H}_{2} \mathrm{O} \rightleftharpoons \mathrm{H}^{+}+\mathrm{HSO}_{3}^{-}$ & $1.7 \times 10^{-2} \exp \left(2090 T^{*}\right)$ \\
\hline $\mathrm{HSO}_{3}^{-} \rightleftharpoons \mathrm{H}^{+}+\mathrm{SO}_{3}^{2-}$ & $6.0 \times 10^{-8} \exp \left(1120 T^{*}\right)$ \\
\hline $\mathrm{HNO}_{3} \rightleftharpoons \mathrm{NO}_{3}^{-}+\mathrm{H}^{+}$ & $1.8 \times 10^{-5} \exp \left(-450.0 T^{*}\right)$ \\
\hline $\mathrm{NH}_{3}+\mathrm{H}_{2} \mathrm{O} \rightleftharpoons \mathrm{NH}_{4}^{+}+\mathrm{OH}^{-}$ & $1.8 \times 10^{-5} \exp \left(-450.0 T^{*}\right)$ \\
\hline $\mathrm{CO}_{2}+\mathrm{H}_{2} \mathrm{O} \rightleftharpoons \mathrm{H}^{+}{ }^{4}+\mathrm{HCO}_{3}^{-}$ & $4.3 \times 10^{-7} \exp \left(-913.0 T^{*}\right)$ \\
\hline $\mathrm{H}_{2} \mathrm{O} \rightleftharpoons \mathrm{H}^{+}+\mathrm{OH}^{-}$ & $1.0 \times 10^{-14} \exp \left(-6716.0 T^{*}\right)$ \\
\hline Aqueous-phase reactions & Rate constants $^{d}$ \\
\hline $\mathrm{HSO}_{3}^{-}+\mathrm{H}_{2} \mathrm{O}_{2} \rightarrow \mathrm{H}^{+}+\mathrm{SO}_{4}^{2-}+\mathrm{H}_{2} \mathrm{O}$ & $\left(\left[\mathrm{H}^{+}\right] /\left(\left[\mathrm{H}^{+}\right]+0.1\right)\right) 5.2 \times 10^{6} \exp \left(-3650 T^{*}\right)$ \\
\hline $\mathrm{HSO}_{3}^{-}+\mathrm{O}_{3} \rightarrow \mathrm{H}^{+}+\mathrm{SO}_{4}^{2-}+\mathrm{O}_{2}$ & $4.2 \times 10^{5} \exp \left(-4131 T^{*}\right)$ \\
\hline $\mathrm{SO}_{3}^{2-}+\mathrm{O}_{3} \rightarrow \mathrm{SO}_{4}^{2-}+\mathrm{O}_{2}$ & $1.5 \times 10^{9} \exp \left(-996 T^{*}\right)$ \\
\hline \multicolumn{2}{|c|}{${ }^{a}$ Units $\left(\mathrm{cm}^{3} \text { molecule }{ }^{-1}\right)^{(\text {no. of reactants }-1)} \mathrm{s}^{-1}$} \\
\hline \multicolumn{2}{|c|}{ 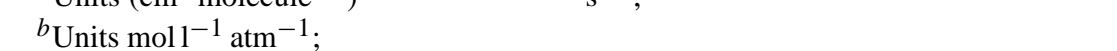 } \\
\hline \multicolumn{2}{|c|}{${ }^{c}$ Units $\left(\mathrm{moll}^{-1}\right)^{(\text {no. of products }- \text { no. of reactants) }}$} \\
\hline \multicolumn{2}{|c|}{${ }^{d}$ Units moll ${ }^{-1} \mathrm{~s}^{-1}$} \\
\hline \multicolumn{2}{|c|}{$\begin{aligned}{ }^{e} \mathrm{~A} 1 & =[\mathrm{M}] 3.0 \times 10^{-31}(\mathrm{~T} / 300)^{-3.3} ; \mathrm{A} 2=1.5 \times 10^{-12} ; \mathrm{A} 3=0.6 ; \mathrm{A} 4=0.75-1.27 \log _{10} \mathrm{~A} 3 \\
\mathrm{~A} 5 & =\mathrm{A} 1 / \mathrm{A} 2 ; \mathrm{A} 6=\mathrm{A} 1 /(1+\mathrm{A} 5) ; \mathrm{A} 7=1+\left(\log _{10} \mathrm{~A} 5 / \mathrm{A} 4\right)^{2} ;\end{aligned}$} \\
\hline \multicolumn{2}{|c|}{ 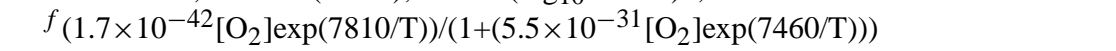 } \\
\hline
\end{tabular}


Table 2. Emissions for the 1990 scenario. Units are $\mathrm{Tg} \mathrm{yr}^{-1}$, except $\mathrm{SO}_{2}$ and $\mathrm{DMS}$ emissions which are $\mathrm{Tg}(\mathrm{S}) \mathrm{yr}^{-1}$, and $\mathrm{NO}_{\mathrm{x}}$ and $\mathrm{NH}_{3}$ emissions which are $\mathrm{Tg}(\mathrm{N}) \mathrm{yr}^{-1}$. "Other natural" includes $8.8 \mathrm{Tg}(\mathrm{S}) \mathrm{yr}^{-1}$ from background volcanic emissions, $5 \mathrm{Tg}(\mathrm{N}) \mathrm{yr}^{-1}$ from lightning, $69 \mathrm{Tg}\left(\mathrm{CH}_{4}\right) \mathrm{yr}^{-1}$ from tundra, $89 \mathrm{Tg}\left(\mathrm{CH}_{4}\right) \mathrm{yr}^{-1}$ from wetlands, and $27 \mathrm{Tg}\left(\mathrm{CH}_{4}\right) \mathrm{yr}^{-1}$ from termites. Anthropogenic $\mathrm{NO}_{\mathrm{x}}$ includes $0.5 \mathrm{Tg}(\mathrm{N}) \mathrm{yr}^{-1}$ from aircraft

\begin{tabular}{lrrrrrrr}
\hline Species & Anthropogenic & $\begin{array}{r}\text { Biomass } \\
\text { burning }\end{array}$ & Vegetation & Soils & Oceans & $\begin{array}{r}\text { Other } \\
\text { natural }\end{array}$ & Total \\
\hline $\mathrm{SO}_{2}$ & 71.2 & 1.4 & - & - & - & 8.8 & 81.4 \\
$\mathrm{DMS}_{\mathrm{NH}}$ & - & - & - & 1.0 & 15.0 & - & 16.0 \\
$\mathrm{NO}_{x}$ & 39.3 & 3.5 & - & 2.4 & 8.2 & - & 53.4 \\
$\mathrm{CH}_{4}$ & 23.3 & 7.1 & - & 5.6 & - & 5.0 & 41.0 \\
$\mathrm{CO}$ & 282.0 & 55.0 & - & - & 13.0 & 185.0 & 535.0 \\
$\mathrm{H}_{2}$ & 393.0 & 500.0 & 150.0 & - & 50.0 & - & 1093.0 \\
$\mathrm{C}_{2} \mathrm{H}_{6}$ & 20.0 & 20.0 & - & 5.0 & 5.0 & - & 50.0 \\
$\mathrm{C}_{3} \mathrm{H}_{8}$ & 5.1 & 3.6 & 3.5 & - & - & - & 12.2 \\
$\mathrm{C}_{4} \mathrm{H}_{10}$ & 5.3 & 1.0 & 3.5 & - & 0.5 & - & 10.3 \\
$\mathrm{C}_{2} \mathrm{H}_{4}$ & 45.8 & 2.1 & 8.0 & - & - & - & 55.9 \\
$\mathrm{C}_{3} \mathrm{H}_{6}$ & 5.8 & 7.1 & 20.0 & - & - & - & 32.9 \\
$\mathrm{C}_{5} \mathrm{H}_{8}$ & 7.9 & 8.2 & 20.0 & - & - & - & 36.1 \\
$\mathrm{C}_{7} \mathrm{H}_{8}$ & - & - & 450.0 & - & - & - & 450.0 \\
$\mathrm{C}_{8} \mathrm{H}_{10}$ & 7.1 & 5.5 & - & - & - & - & 12.6 \\
$\mathrm{HCHO}$ & 7.2 & 1.1 & - & - & - & - & 8.3 \\
$\mathrm{CH}_{3} \mathrm{CHO}$ & 1.1 & 1.3 & - & - & - & - & 2.4 \\
$\mathrm{CH}_{3} \mathrm{OH}$ & 2.5 & 4.0 & - & - & - & - & 6.5 \\
$\mathrm{CH}_{3} \mathrm{COCH}$ & 6.0 & 7.5 & - & - & - & - & 13.5 \\
\hline
\end{tabular}

Brasseur et al., 1998; Wang and Jacob, 1998; Mickley et al., 1999; Hauglustaine and Brasseur, 2001).

For the 1990 scenario, anthropogenic emissions distributions and totals from the EDGAR database (Olivier et al., 1996) are used. All anthropogenic categories except biomass burning are included, for $\mathrm{NO}_{\mathrm{x}}, \mathrm{CO}, \mathrm{CH}_{4}, \mathrm{SO}_{2}, \mathrm{NH}_{3}$, and NMHCs. We use the term anthropogenic for these lumped emissions that exclude biomass burning, although burning has both anthropogenic and natural components. The anthropogenic emissions have no seasonal variation.

For biomass burning, we use monthly varying magnitudes and distributions from Cooke and Wilson (1996), together with totals from IPCC OxComp (Prather et al., 2001). Emissions from vegetation (Guenther et al., 1995), soils (Yienger and Levy, 1995), wetlands, tundra (Matthews and Fung, 1987) and the oceans also vary monthly. Isoprene $\left(\mathrm{C}_{5} \mathrm{H}_{8}\right)$ emissions from vegetation are linked to local solar zenith angle, as they are light and temperature sensitive. Four-dimensional (latitude-longitude-altitude-month) emissions of $\mathrm{NO}_{\mathrm{x}}$ from lightning (Price and Rind, 1992) and aircraft (Isaksen et al., 1999) (for the 1990 case) are included.

Background volcanic $\mathrm{SO}_{2}$ emissions total $8.8 \mathrm{Tg}(\mathrm{S}) \mathrm{yr}^{-1}$, based upon emissions for 1980 (Spiro et al., 1992). These data show peaks associated with the Mt. St. Helens eruption in 1980, and the continuous high $\mathrm{SO}_{2}$ output from Mt. Etna on Sicily. Whilst volcanic emissions vary considerably in time and space (Andres and Kasgnoc, 1998), having spikes associated with eruptions, these emissions are thought to give a reasonable representation of the typical distributions and magnitudes of background volcanic emissions. The emissions are added to the model over the vertical range from the surface up to $\sim 300 \mathrm{hPa}$, as most volcanic $\mathrm{SO}_{2}$ is released during explosive eruptions and from elevated sources, directly entering the free troposphere (Graf et al., 1997). The model's present-day sulphur cycle is analysed in more detail in Stevenson et al. (2003).

\subsection{Dry and wet deposition}

Within the boundary layer, dry deposition rates are calculated using a resistance analogy scheme (e.g., Seinfeld and Pandis (1998)), with inputs of species-dependent deposition velocities, the boundary layer height, and an effective vertical eddy diffusion coefficient derived from the surface stress, heat flux, and temperature. There is no dependence of deposition on vegetation type. Deposition velocities vary between land, sea and ice, with values for $\mathrm{SO}_{2}$ of 6,8 and $0.5 \mathrm{mms}^{-1}$ respectively (Erisman and Baldocchi, 1994), and values for sulphate $\left(\mathrm{SA}\right.$ and $\left.\left(\mathrm{NH}_{4}\right)_{2} \mathrm{SO}_{4}\right)$ of 2,1 , and $0.05 \mathrm{mms}^{-1}$ (Wesely et al., 1985). Several other important species are dry deposited, including $\mathrm{H}_{2} \mathrm{O}_{2}, \mathrm{O}_{3}, \mathrm{NO}_{2}$ and $\mathrm{NH}_{3}$.

Soluble species are subject to wet removal, through precipitation scavenging. This includes $\mathrm{SO}_{2}$, sulphate, $\mathrm{H}_{2} \mathrm{O}_{2}$ and 
$\mathrm{NH}_{3}$. Species-dependent scavenging coefficients are taken from Penner et al. (1994), and vary between dynamic and convective precipitation. Coefficients for $\mathrm{SO}_{2}$ are 0.8 and $1.5 \mathrm{~cm}^{-1}$ for dynamic and convective precipitation, respectively. Equivalent values for sulphuric acid aerosol are 5.0 and $1.5 \mathrm{~cm}^{-1}$. These coefficients are then used with precipitation rates, and scavenging profiles, to calculate loss rates for all soluble species from each air parcel. The normalised scavenging profile for dynamic precipitation increases linearly with pressure from zero at $400 \mathrm{hPa}$ to one at $800 \mathrm{hPa}$, remaining at this value down to the surface. A similar profile is used for convective precipitation, but with the profile starting at the cloud top. Wet scavenging is only activated when the precipitation rate exceeds $10^{-8} \mathrm{kgm}^{-2} \mathrm{~s}^{-1}$. Very little wet deposition occurs outside the tropics at altitudes above $\sim 400 \mathrm{hPa}$, due to the lack of deep convection in these regions.

2.5 Stratospheric ozone and stratosphere-troposphere exchange

Ozone is a gas crucial to tropospheric chemistry, and needs to be simulated realistically in order to accurately calculate other oxidants such as $\mathrm{OH}$ and $\mathrm{H}_{2} \mathrm{O}_{2}$. Several other studies with STOCHEM have focussed upon tropospheric $\mathrm{O}_{3}$ (Collins et al., 1997, 2000; Stevenson et al., 1998b). The input of stratospheric $\mathrm{O}_{3}$ is an important part of the tropospheric $\mathrm{O}_{3}$ budget. Previous versions of STOCHEM only extended to $\sim 100 \mathrm{hPa}$, and estimated the influx using vertical velocities and an $\mathrm{O}_{3}$ climatology ( $\mathrm{Li}$ and Shine, 1995) in the lower stratosphere. In this work, we impose this $\mathrm{O}_{3}$ climatology above the tropopause, and allow the advection scheme to transport $\mathrm{O}_{3}$ downwards. To limit downwards mixing, no inter-air parcel mixing across the tropopause is allowed, so cross-tropopause transfer is achieved only through advection. Most current CTMs (Prather et al., 2001) parameterise or limit stratosphere-troposphere exchange (STE) to generate realistic influxes of $\mathrm{O}_{3}$, because they lack tropopause resolution. However, because STOCHEM-Ed has a high resolution tropopause, we find that the source of stratospheric $\mathrm{O}_{3}$ is realistic $\left(\sim 450 \mathrm{Tg}\left(\mathrm{O}_{3}\right) \mathrm{yr}^{-1}\right)$ using the true advection. This suggests that STE in general should also be reasonable, and this will be important in realistically transporting volcanic emissions and their products in the tropopause region.

\section{Experiments}

Two years of meteorological data generated by the GCM were used to drive five repeat experiments with STOCHEMEd. These data did not vary between experiments, only the emissions changed. It should be noted that no attempt was made to simulate the meteorological conditions of 17831784. Synoptic daily weather maps of the 1780 s over Europe have been constructed (Kington, 1978, 1988), and there is also evidence that a strong El Niño occurred during 17821783 (Ortlieb, 1993). Further simulations of the Laki eruption may benefit from the assimilation of this meteorological data, however this was not attempted here. Rather, we use the GCM to generate data representative of the 1990s. The results should not, therefore, be expected to simulate the observed day-by-day spread of the aerosol. However, they should indicate an approximate evolution of the aerosol cloud under a typical time-varying meteorology. Previous experiments using a different year's meteorology produced qualitatively similar results (Stevenson et al., 2001). Each integration started in September, and continued for 17 months. The first 4 months are considered as spin-up of STOCHEMEd, and are not used in the following analysis. The GCM is initialised from a dump for September 1996, and is already fully spun-up.

The five emission scenarios represented atmospheres of the present-day (1990), the pre-industrial era (prior to c.1860), and three cases for the pre-industrial with the emissions from the Laki eruption superimposed. The three Laki simulations use the same magnitude of emissions, but apply different vertical profiles and temporal evolutions. In the first case (termed "Lo"), emissions are evenly distributed form the surface to $\sim 300 \mathrm{hPa}(\sim 9 \mathrm{~km})$. In the other two cases ("Hi" and "Hi_pulse"), $25 \%$ of the $\mathrm{SO}_{2}$ is emitted between the surface and $\sim 700 \mathrm{hPa}(\sim 3 \mathrm{~km})$, and $75 \%$ around tropopause levels $(\sim 300-175 \mathrm{hPa} ; \sim 9-13 \mathrm{~km})$. In total, $32 \%$ of the emissions are above the tropopause. The estimated vertical profile of emissions is derived from models of volcanic eruption columns (e.g., Woods (1993)), driven by estimates of the magma eruption rate, gas content, and vent morphology, all of which can be estimated from eyewitness accounts of the eruption and examination of the eruption products (Thordarson and Self, 2003).

The real vertical profile of emissions is unknown, but is probably more likely to resemble the "Hi" cases, as most volcanic gases will be released during the most explosive phases of the eruption (which also reach the greatest altitudes), and are likely to be detrained from the top of the eruption cloud (Woods, 1993). A significant amount of $\mathrm{SO}_{2}$ was also probably released close to the surface, directly from the fissures and lava flows. The split of 75\%:25\% was derived from preliminary modelling (S. Self, pers. comm., 2002), and is similar to the ratio of 80\%:20\% reported by Thordarson and Self (2003). The "Lo" case, with a higher proportion of gas released at lower levels, reflects the uncertainty in this split, the uncertainties in the actual heights of the eruption clouds, and the possibility that some of the gas could be detrained before reaching the cloud top. As such, the "Lo" case probably represents the lowest reasonable range of altitudes for the $\mathrm{SO}_{2}$ emission.

For the Laki simulations, we added an extra source of $\mathrm{SO}_{2}$ to the grid over Iceland, using the emissions estimated by Thordarson et al. (1996), which total $61 \mathrm{Tg}(\mathrm{S})$. Thordarson et al. (1996) described the evolution of the eruption, and 


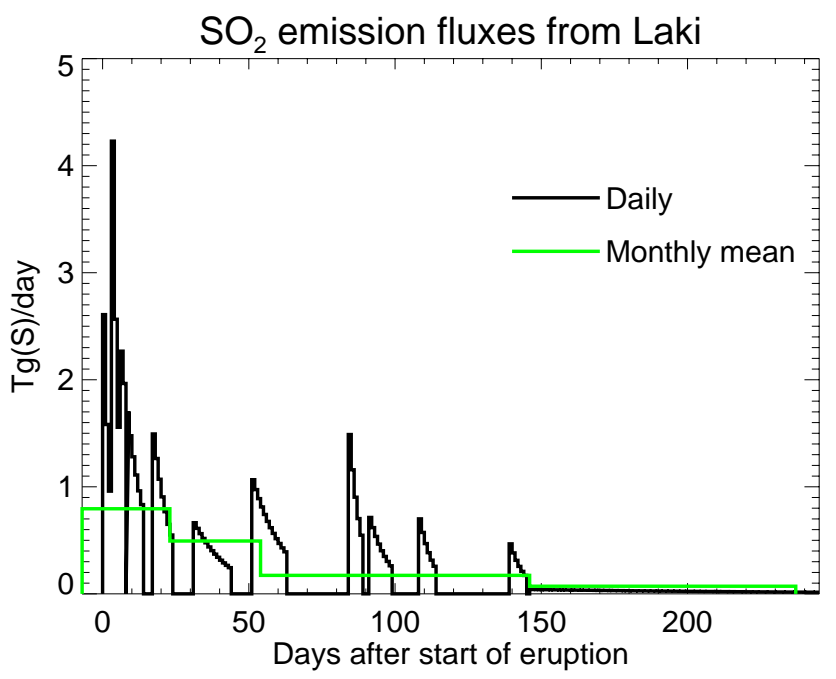

Fig. 1. Laki $\mathrm{SO}_{2}$ emissions. Monthly mean emissions are derived from Thordarson et al. (1996) and are used in the Laki Lo and Hi scenarios. Daily emissions are derived from Thordarson and Self (2003), and assume emissions fall to (1/e) of their initial value by the final day of each episode. Daily emissions are used in the Hi_pulse scenario. Note that monthly emissions differ somewhat between the two cases, but total emissions are the same.

estimated the associated $\mathrm{SO}_{2}$ emissions using the "petrologic method". This technique takes advantage of the fact that glass inclusions, trapped within phenocrysts in the lava, represent samples of undegassed magma. By analysing the sulphur content of these inclusions, together with the sulphur content of degassed lava, the quantity of sulphur released per unit volume of magma erupted was deduced. Unfortunately, Thordarson et al. (1996) fail to report an uncertainty associated with the total emissions. These authors do report uncertainties in the glass inclusion analyses of between $\pm 5 \%$ and $\pm 17 \%$. Coupled with an uncertainty in the total volume of magma released, we estimate an uncertainty of at least $\pm 20 \%$ on the figure of $61 \mathrm{Tg}(\mathrm{S})$. The petrologic method is generally accepted to give a minimum for the gas released upon eruption (Wallace, 2001), which suggests that the real emission is more likely to be larger than $61 \mathrm{Tg}(\mathrm{S})$. There are further uncertainties associated with processes in the eruption plume itself which we are unable to quantify here.

Using historical data from observations, the variation of the eruption rate with time was also estimated. These two quantities yield the time evolution of the sulphur emissions (Fig. 1). The daily emissions have been calculated using emissions attributed to each of a series of episodes documented by Thordarson and Self (2003). For each episode, emissions are assumed to fall to (1/e) of their initial value by the last day of the episode. Between episodes, emissions are assumed to be zero. These daily emissions have been used in the "Hi_pulse" scenario. For the "Lo" and "Hi" scenarios we used monthly mean emissions in the simulations, and added them between 1 June and 31 January, rather than the actual dates of the eruption (8 June 1783 to 7 February 1784). Thordarson et al. (1996) estimated that $60 \%$ of the $\mathrm{SO}_{2}$ was released in the first 1.5 months, a further $30 \%$ over the next 3.5 months, and the remaining $10 \%$ during the final 3 months. These figures translate to $0.80 \mathrm{Tg}(\mathrm{S})$ day $^{-1}$ in June, $0.49 \mathrm{Tg}(\mathrm{S})$ day $^{-1}$ in July, $0.35 \mathrm{Tg}(\mathrm{S})$ day $^{-1}$ between August and October, and $0.14 \mathrm{Tg}(\mathrm{S})$ day $^{-1}$ from November to the end of January. It should be noted that the daily emissions, when averaged monthly, do not generate exactly the same time evolution; this reflects differences in the eruption evolution reported by Thordarson et al. (1996) and Thordarson and Self (2003).

\section{Results and discussion}

\subsection{Sulphur dioxide and oxidants}

Figure 2 shows zonal June-July-August (JJA) mean $\mathrm{SO}_{2}$ for 1990, 1860, and the three Laki experiments. Table 3 shows annual mean and JJA global budgets for $\mathrm{SO}_{2}$ and sulphate for all experiments, showing the figures for Laki relative to 1860. For the 1990 scenario, annual $\mathrm{SO}_{2}$ emissions total 81.3 $\operatorname{Tg}(\mathrm{S})$, from anthropogenic, volcanic, and biomass burning sources. A further $11.7 \mathrm{Tg}(\mathrm{S}) \mathrm{yr}^{-1}$ comes from the oxidation of DMS, yielding a total annual $\mathrm{SO}_{2}$ source of $93 \mathrm{Tg}(\mathrm{S})$. The 1860 scenario has the same volcanic source, $20 \%$ of the biomass burning source, and no anthropogenic source. The 1860 DMS source remains the same, but slightly more $\mathrm{SO}_{2}$ is generated from it, due to small changes in the DMS oxidation chemistry. The Laki scenarios are the same as the 1860 scenario, with the addition of $61 \mathrm{Tg}(\mathrm{S})$ over Iceland for the 8 months June to January.

In the 1990 scenario, $41 \%$ of the $\mathrm{SO}_{2}$ is deposited to the surface, predominantly by dry deposition. The remaining $\mathrm{SO}_{2}$ is converted to sulphate aerosol, partly by gas-phase $\mathrm{OH}$ oxidation (6\%), but mainly by aqueous-phase oxidation, through the reactions involving $\mathrm{H}_{2} \mathrm{O}_{2}(34 \%)$ and $\mathrm{O}_{3}(18 \%)$. The total $\mathrm{SO}_{2}$ atmospheric burden is $0.29 \mathrm{Tg}(\mathrm{S})$, and dividing this by the total loss rate gives a global annual mean lifetime $\left(\tau_{\mathrm{SO}_{2}}\right)$ of 1.1 days. Several recent model studies of the present-day tropospheric sulphur cycle are reviewed by Koch et al. (1999), and have burdens in the range $0.20-0.61 \mathrm{Tg}(\mathrm{S})$ and lifetimes of 0.6-2.6 days. Results from STOCHEM-Ed are towards the lower end of these ranges. Figure $3 \mathrm{a}$ shows the zonal JJA mean $\tau_{\mathrm{SO}_{2}}$ for 1990 , calculated from the zonal mean $\mathrm{SO}_{2}$ distribution (Fig. 2a) and the zonal mean total loss rate for $\mathrm{SO}_{2}$, from both oxidation and deposition. Lifetimes range from 0.2 days in the marine boundary layer of the Southern oceans to over 50 days in the polar upper troposphere (UT). One reason for the increase in lifetime with altitude is the general decrease in abundance of clouds with altitude in the free troposphere, limiting the aqueous oxidation pathway. In the tropics, $\tau_{\mathrm{SO}_{2}}$ is under 2 days almost through- 
(a) 1990

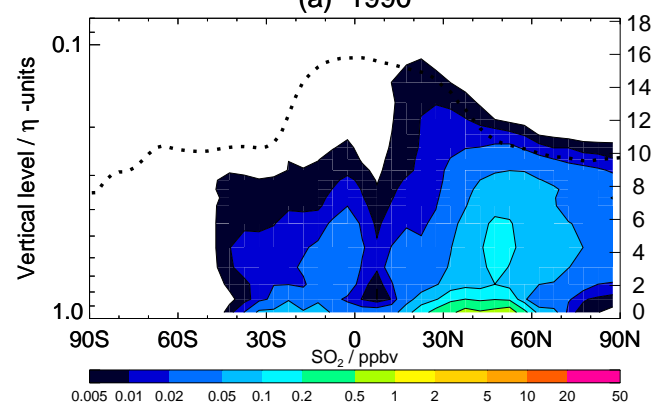

(c) Laki Lo

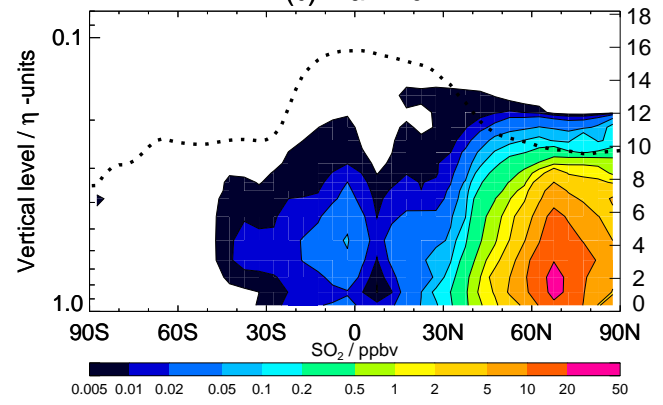

(e) Laki Hi_pulse

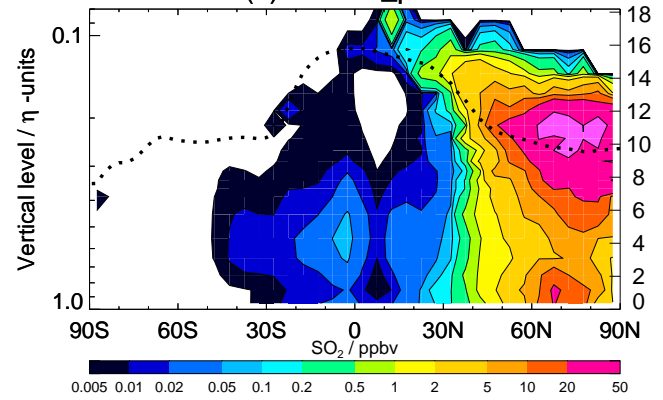

(b) 1860

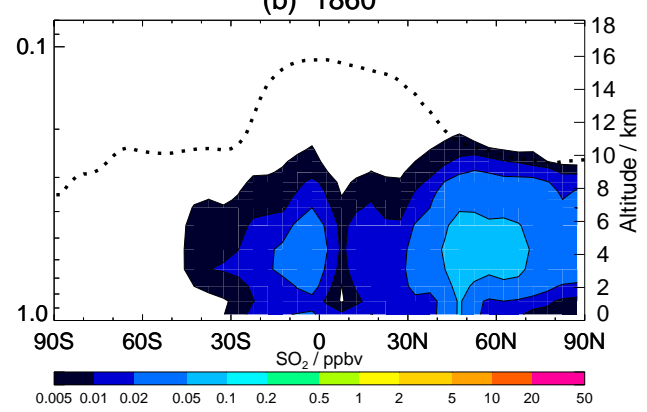

(d) Laki Hi

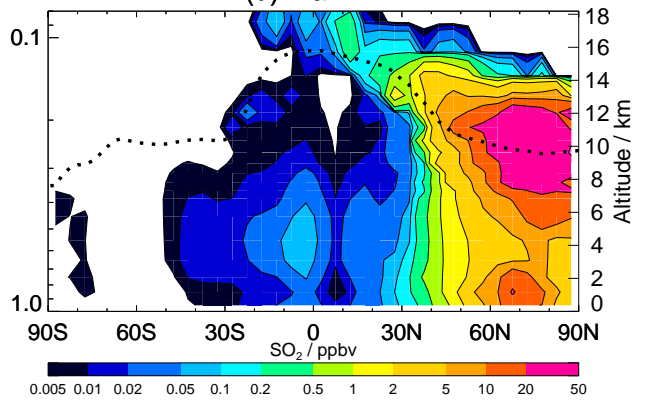

Fig. 2. Zonal, June-July-August (JJA) mean $\mathrm{SO}_{2}$ concentrations (ppbv) for: (a) 1990; (b) 1860; (c) Laki Lo; (d) Laki Hi; and (e) Laki Hi_pulse. The dotted line is the tropopause.

out the troposphere. At Icelandic latitudes, $\tau_{\mathrm{SO}_{2}}$ lengthens from about 0.5 days at the surface to over 10 days in the UT. The short lifetime of $\mathrm{SO}_{2}$ leads to steep gradients in concentration around the source regions and low concentrations at sites remote from these emissions (Fig. 2a).

In the 1860 scenario, where much of the $\mathrm{SO}_{2}$ originates from volcanoes and is released at higher altitudes, a smaller fraction (19\%) is deposited. Compared to 1990, a slightly larger fraction goes through the $\mathrm{H}_{2} \mathrm{O}_{2}$ oxidation route rather than the $\mathrm{O}_{3}$ reaction. Both $\mathrm{O}_{3}$ and $\mathrm{H}_{2} \mathrm{O}_{2}$ were lower in preindustrial times, but whilst $\mathrm{H}_{2} \mathrm{O}_{2}$ increases since 1860 have been centred on the tropics, $\mathrm{O}_{3}$ increases have been mainly in the Northern Hemisphere ( $\mathrm{NH})$, co-located with the rising industrial $\mathrm{SO}_{2}$ emissions. This explains the greater importance of the $\mathrm{O}_{3}$ oxidation path in the 1990 simulation. The 1860 $\mathrm{SO}_{2}$ burden is $33 \%$ of the 1990 value, and its global annual mean lifetime is 1.6 days (44\% longer than in 1990). Figure $3 \mathrm{~b}$ reveals a slightly shorter $\mathrm{SO}_{2}$ lifetime near the surface in 1860 compared to 1990 , but a longer lifetime in the free troposphere. The longer globally averaged lifetime reflects both the higher mean altitude of emissions, and the lower levels of the main oxidants at these levels. Figure $2 \mathrm{~b}$ shows the $\mathrm{SO}_{2}$ distribution for JJA 1860. When compared with Fig. 2a, many similar features can be seen, particularly in the tropics and the SH. These are due to the common natural emissions' sources in these two scenarios. The peak values in the pre-industrial NH are mainly due to volcanic emissions from Italy, N. America, Iceland and E. Asia.

Figures 2c-e show JJA $\mathrm{SO}_{2}$ distributions for the Laki cases. This shows that Laki enhanced summer $\mathrm{SO}_{2}$ zonally by over $20 \mathrm{ppbv}$, with concentrations over 100 times higher than peak values in 1860. Large increases in $\mathrm{SO}_{2}$ are seen polewards of $\sim 30^{\circ} \mathrm{N}$. In the Laki Lo case, the $\mathrm{SO}_{2}$ perturbation is limited to the troposphere, but in the Laki Hi cases, some of the high level emissions are transported equatorwards in the lower stratosphere (LS). Longer $\mathrm{SO}_{2}$ lifetimes at altitude generate higher $\mathrm{SO}_{2}$ concentrations, particularly polewards of $60^{\circ} \mathrm{N}$. Lower tropospheric concentrations are similar in all three Laki cases. 
(a) 1990

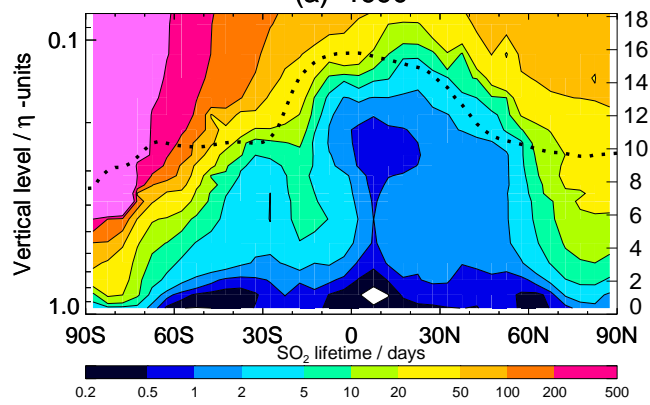

(c) Laki Lo

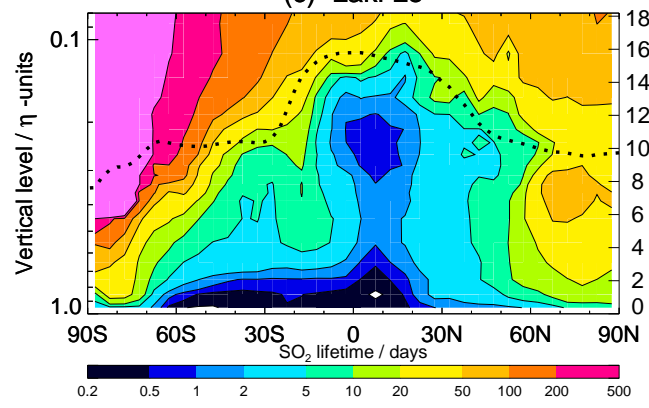

(d) Laki Hi_pulse

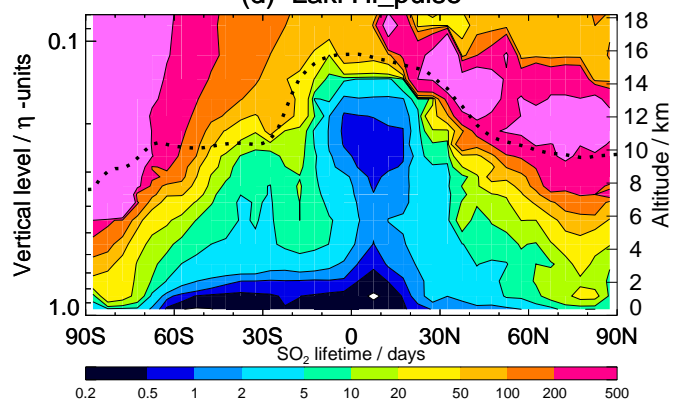

(b) 1860

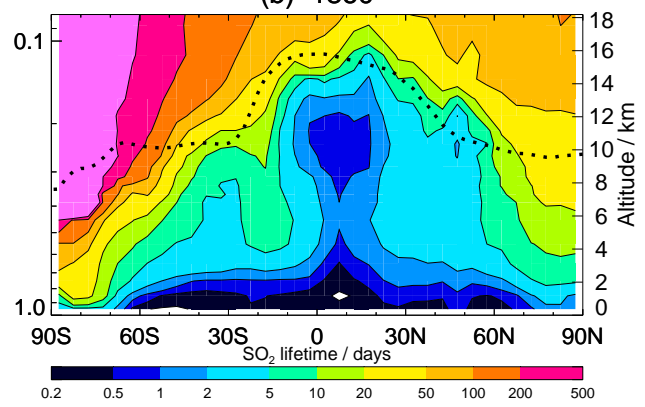

(d) Laki Hi

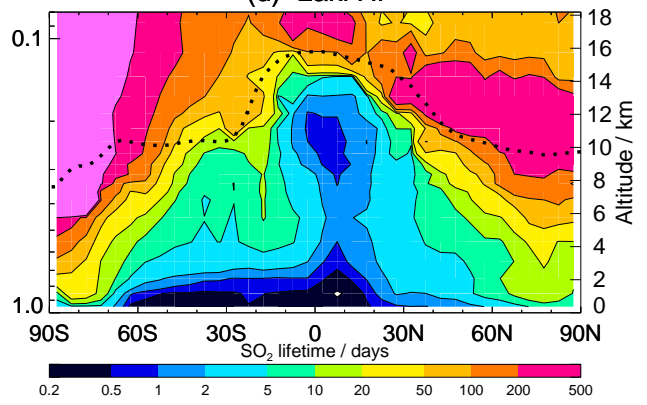

Fig. 3. Zonal, June-July-August (JJA) mean $\mathrm{SO}_{2}$ lifetimes (days) for: (a) 1990; (b) 1860; (c) Laki Lo; (d) Laki Hi; and (e) Laki Hi_pulse. The dotted line is the tropopause.

By looking at the difference in the budgets between the Laki and 1860 scenarios, we can see the simulated fate of the $\mathrm{SO}_{2}$ emitted by Laki. Most (64-72\%) of the emitted $\mathrm{SO}_{2}$ is deposited to the surface, roughly equally divided between wet and dry deposition. The remaining $\mathrm{SO}_{2}$ is converted to aerosol, with about half being oxidised in the gas-phase, the rest mainly through the $\mathrm{H}_{2} \mathrm{O}_{2}$ reaction. This is in contrast to the 1860 atmosphere, where aqueous-phase oxidation dominates over deposition and gas-phase oxidation. Comparing the Laki and 1860 scenarios for JJA, oxidation in the gasphase increases by a factor of $12-14$, but in the aqueousphase only increases by a factor of 2.3-2.7. The high levels of $\mathrm{SO}_{2}$ cause depletion of its oxidants (Fig. 4). $\mathrm{H}_{2} \mathrm{O}_{2}$ is most strongly affected, and aqueous-phase oxidation approaches saturation more rapidly than gas-phase oxidation. The largest depletions in $\mathrm{H}_{2} \mathrm{O}_{2}$, of over $30 \%$ in the zonal JJA field, occur in the cloudy storm-track regions $\left(50-65^{\circ} \mathrm{N}\right)$. OH depletion reaches $18 \%$, and is co-located with the regions of $\mathrm{SO}_{2}$ increase (Fig. 2). Over the relatively cloud-free Arctic, $\mathrm{H}_{2} \mathrm{O}_{2}$ shows small increases, due to a chemical feedback associated with the $\mathrm{OH}$ depletion. Tropospheric ozone is also slightly reduced (typically by $1-2 \%$ ), but this is mainly related to lowering of $\mathrm{NO}_{\mathrm{x}}$ associated with the elevated aerosol concentrations (Eq. 1), rather than chemical reaction with dissolved $\mathrm{SO}_{2}$. These oxidant depletions cause increases in $\tau_{\mathrm{SO}_{2}}$ (Fig. 3c-e). The lifetime of the Laki $\mathrm{SO}_{2}$ is 9-20 days, 6-12 times the background 1860 value (Table 3). These increases are partly due to the fact that the Laki emissions are in a region of the atmosphere where $\tau_{\mathrm{SO}_{2}}$ is greater than the global mean value, and partly because oxidants are depleted by the massive $\mathrm{SO}_{2}$ injection.

The average lifetime of the Laki $\mathrm{SO}_{2}$ appears to be surprisingly short, given the $\mathrm{SO}_{2}$ distributions (Fig. 2) and the zonal mean lifetime (Fig. 3). However, the relatively short lifetime towards the surface tends to dominate the calculation, and limits the concentration increases seen here. In addition, transport from the UT and LS moves $\mathrm{SO}_{2}$ into regions where lifetimes are shorter. Local lifetimes for Laki $\mathrm{SO}_{2}$ in 
Table 3. Sulphur dioxide and sulphate budgets. Fluxes have units of $\operatorname{Tg}(\mathrm{S})$, totalled over the year for the annual figures, and over June-JulyAugust for the JJA figures

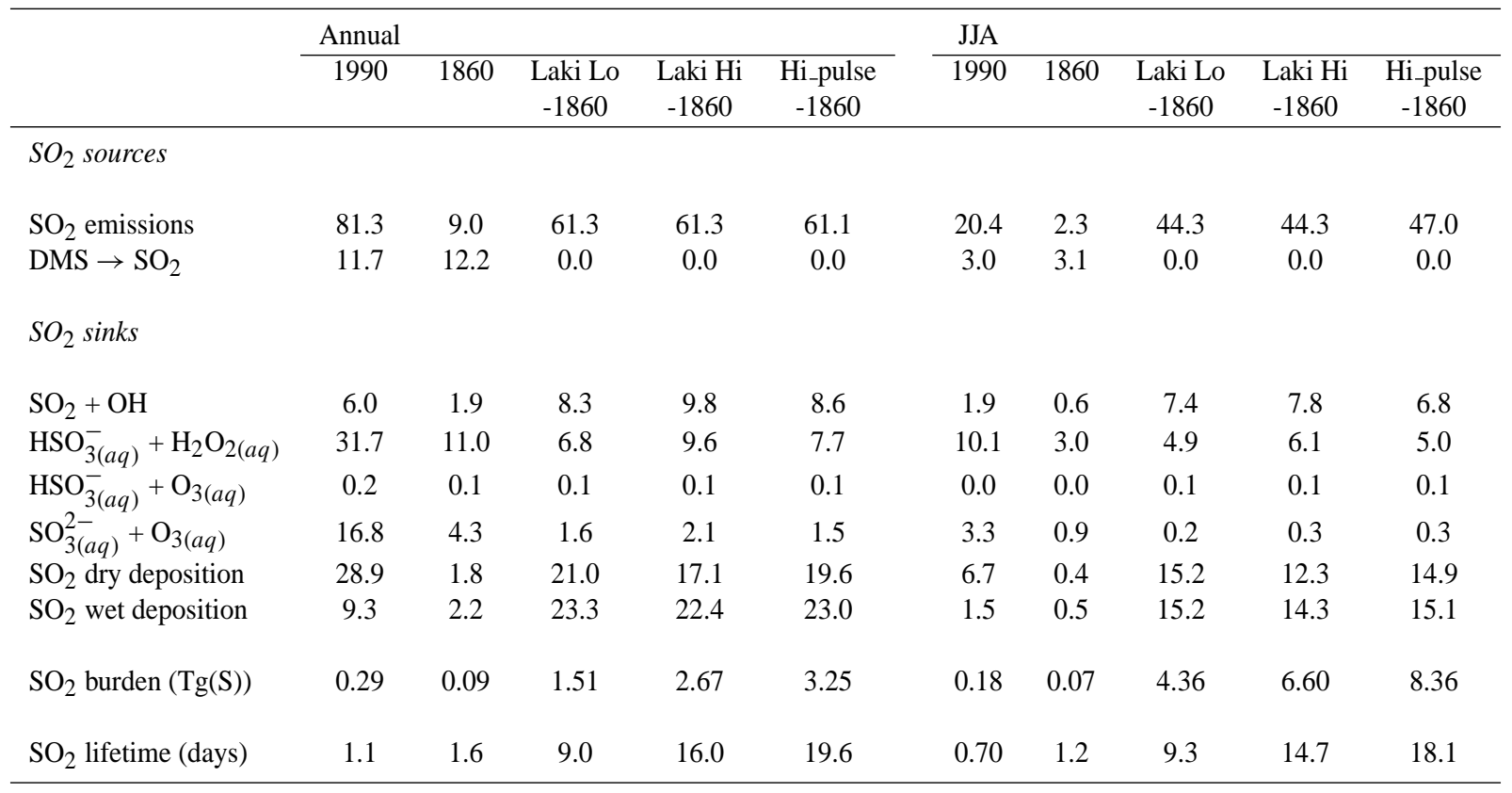

\begin{tabular}{|c|c|c|c|c|c|c|c|c|c|c|}
\hline & \multicolumn{5}{|l|}{ Annual } & \multicolumn{5}{|l|}{ JJA } \\
\hline & 1990 & 1860 & $\begin{array}{c}\text { Laki Lo } \\
-1860\end{array}$ & $\begin{array}{l}\text { Laki Hi } \\
-1860\end{array}$ & $\begin{array}{c}\text { Hi_pulse } \\
-1860\end{array}$ & 1990 & 1860 & $\begin{array}{c}\text { Laki Lo } \\
-1860\end{array}$ & $\begin{array}{c}\text { Laki Hi } \\
-1860\end{array}$ & $\begin{array}{c}\text { Hi_pulse } \\
-1860\end{array}$ \\
\hline \multicolumn{11}{|l|}{ Sulphate sources } \\
\hline $\mathrm{SO}_{2}+\mathrm{OH}$ & 6.0 & 1.9 & 8.3 & 9.8 & 8.6 & 1.9 & 0.6 & 7.4 & 7.8 & 6.8 \\
\hline Aqueous phase $\mathrm{SO}_{2}$ oxidation & 48.8 & 15.4 & 8.5 & 11.7 & 9.3 & 13.4 & 3.9 & 5.1 & 6.5 & 5.3 \\
\hline $\mathrm{DMS} \rightarrow \mathrm{H}_{2} \mathrm{SO}_{4}$ & 0.3 & 0.1 & 0.0 & 0.0 & 0.0 & 0.1 & 0.0 & 0.0 & 0.0 & 0.0 \\
\hline \multicolumn{11}{|l|}{ Sulphate sinks } \\
\hline $\mathrm{H}_{2} \mathrm{SO}_{4}$ dry deposition & 2.6 & 0.7 & 2.0 & 2.1 & 1.8 & 0.9 & 0.2 & 1.5 & 1.4 & 1.2 \\
\hline $\mathrm{H}_{2} \mathrm{SO}_{4}$ wet deposition & 21.4 & 9.7 & 14.7 & 19.2 & 15.8 & 6.1 & 2.5 & 10.3 & 11.6 & 10.0 \\
\hline$\left(\mathrm{NH}_{4}\right)_{2} \mathrm{SO}_{4}$ dry deposition & 4.1 & 0.8 & 0.1 & 0.1 & 0.1 & 1.1 & 0.2 & 0.1 & 0.1 & 0.1 \\
\hline$\left(\mathrm{NH}_{4}\right)_{2} \mathrm{SO}_{4}$ wet deposition & 27.0 & 6.1 & 0.1 & 0.2 & 0.2 & 7.1 & 1.6 & 0.1 & 0.1 & 0.1 \\
\hline $\mathrm{H}_{2} \mathrm{SO}_{4}$ burden $(\mathrm{Tg}(\mathrm{S}))$ & 0.40 & 0.19 & 0.30 & 0.54 & 0.48 & 0.51 & 0.20 & 0.91 & 1.14 & 0.99 \\
\hline$\left(\mathrm{NH}_{4}\right)_{2} \mathrm{SO}_{4}$ burden $(\mathrm{Tg}(\mathrm{S}))$ & 0.41 & 0.09 & 0.0 & 0.0 & 0.0 & 0.45 & 0.10 & 0.0 & 0.0 & 0.0 \\
\hline Total sulphate lifetime (days) & 5.4 & 5.8 & 6.5 & 9.1 & 9.8 & 5.8 & 5.9 & 6.9 & 7.9 & 7.9 \\
\hline
\end{tabular}


(a) Laki Lo

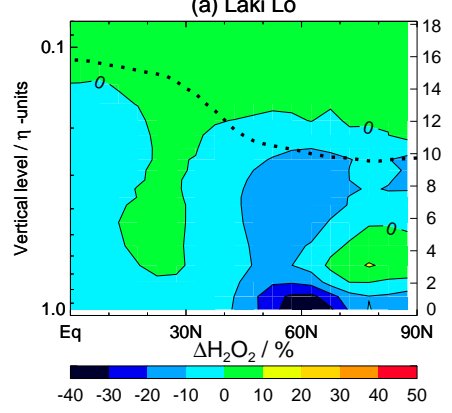

(d) Laki Hi

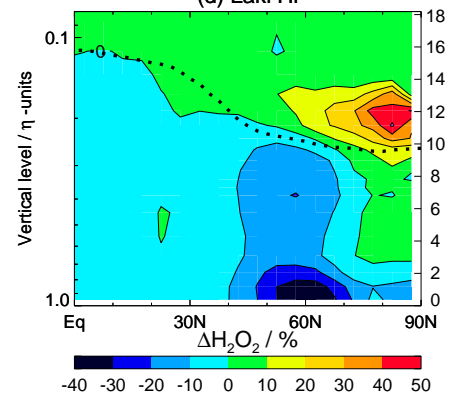

(g) Laki Hi_pulse

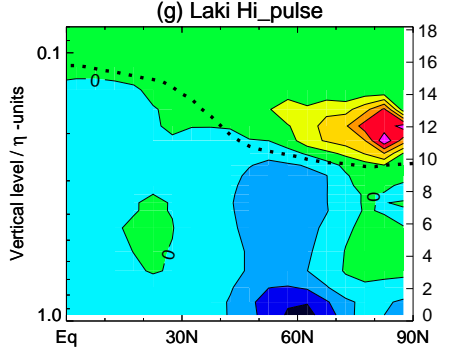

(b) Laki Lo

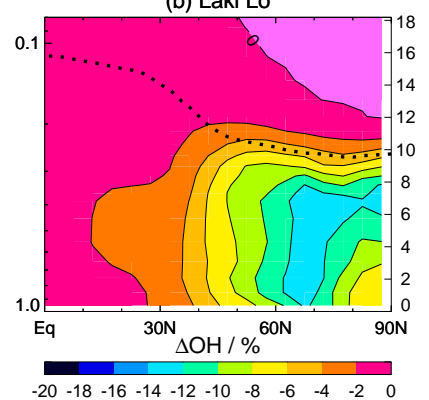

(e) Laki Hi

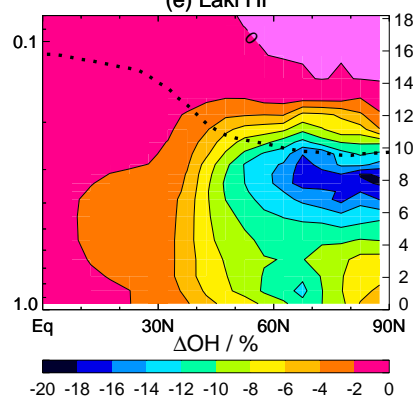

(h) Laki Hi_pulse

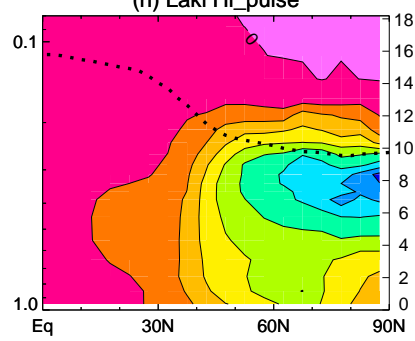

(c) Laki Lo

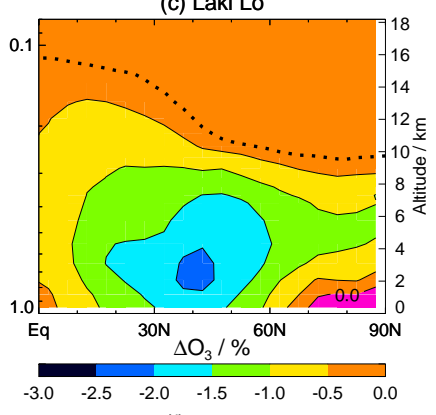

(f) Laki Hi

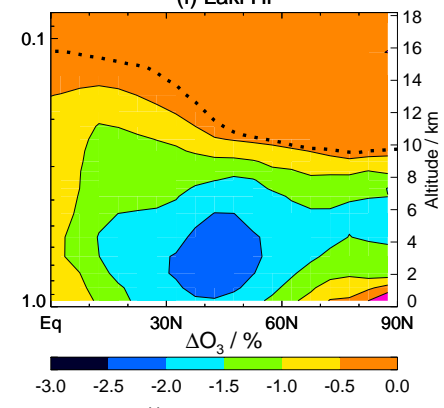

(i) Laki Hi_pulse

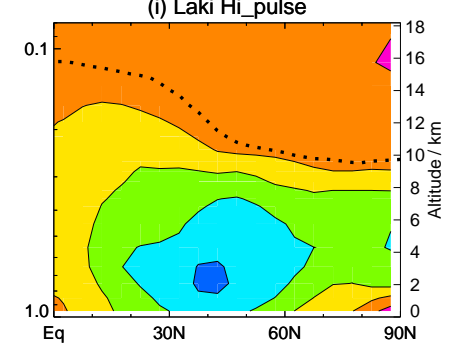

Fig. 4. Northern Hemisphere zonal, June-July-August (JJA) mean oxidant depletions (\%) for Laki Lo (a-c), Laki Hi (d-f), and Laki Hi_pulse $(\mathrm{g}-\mathbf{i})$, relative to 1860 . For each case, changes are plotted for: $\mathrm{H}_{2} \mathrm{O}_{2}(\mathrm{a}, \mathrm{d}, \mathrm{g}) ; \mathrm{OH}(\mathrm{b}, \mathrm{e}, \mathrm{h})$; and $\mathrm{O}_{3}(\mathrm{c}, \mathrm{f}, \mathrm{i})$. The dotted line is the tropopause.

JJA, after accounting for transport effects are 25 days in the LS, 12 days in the UT, and 5.3 days in the LT.

\subsection{Sulphate}

Sulphate is the product of $\mathrm{SO}_{2}$ oxidation; there is also an insignificant pathway direct from DMS (Table 1). Sulphate is partitioned into two species in the model: ammonium sulphate and sulphuric acid. In the 1990 scenario, the relatively high anthropogenic emissions of $\mathrm{NH}_{3}$ mean that over half the sulphate burden exists as ammonium sulphate. In the 1860 scenario, $\mathrm{NH}_{3}$ emissions were lower, and only about a third of the sulphate was ammonium sulphate. The extra sulphate formed following the Laki eruption is almost exclusively sulphuric acid aerosol, as there are very few free ammonium ions. Sulphate distributions (Fig. 5) are smoother and more widespread than their precursor, reflecting the longer sulphate lifetime. Laki sulphate levels reach 1-2 ppbv over much of the summer troposphere polewards of $\sim 50^{\circ} \mathrm{N}$, compared to 1990 levels of 300-500 pptv in NH mid-latitudes.

The only sinks for sulphate are deposition, and wet de- position dominates over dry. Dry deposition only operates in the boundary layer, but wet scavenging occurs throughout and beneath precipitating clouds. The local sulphate lifetime $\left(\tau_{\mathrm{SO}_{4}}\right)$ is therefore determined by purely physical processes, and is invariant between scenarios (Fig. 6). In the UT outside the tropics there are less clouds, and the effective lifetime in these regions is controlled by the timescale of transport into regions where sinks do operate. Global mean $\tau_{\mathrm{SO}_{4}}$ do vary between scenarios, as they also reflect the sulphate distribution. The 1990 scenario has a global annual mean $\tau_{\mathrm{SO}_{4}}$ of 5.4 days, and a burden of $0.81 \mathrm{Tg}(\mathrm{S})$. Like $\mathrm{SO}_{2}$, these values fall within the ranges found in previous modelling studies: $\tau_{\mathrm{SO}_{4}}$ : 3.9-5.7 days; sulphate burden: $0.53-0.96 \mathrm{Tg}(\mathrm{S})$ (Koch et al., 1999). Mean sulphate lifetimes for the Laki cases are up to 10 days, as a significant fraction of the sulphate is in the UT/LS where the local lifetime is relatively long. Local lifetimes for Laki $\mathrm{SO}_{4}$, after accounting for transport effects, are 67 days in the LS, 10 days in the UT, and 5.3 days in the LT. 
(a) 1990

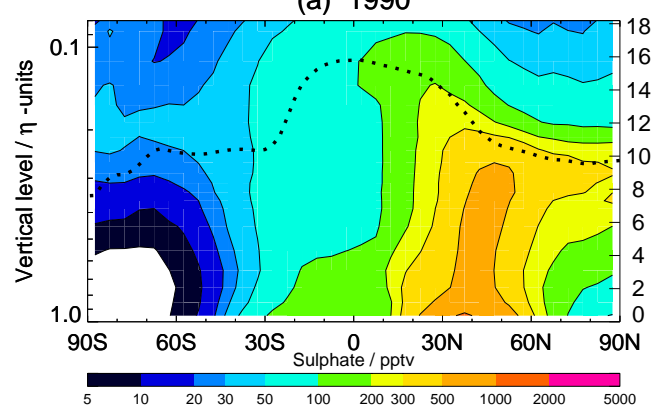

(c) Laki Lo

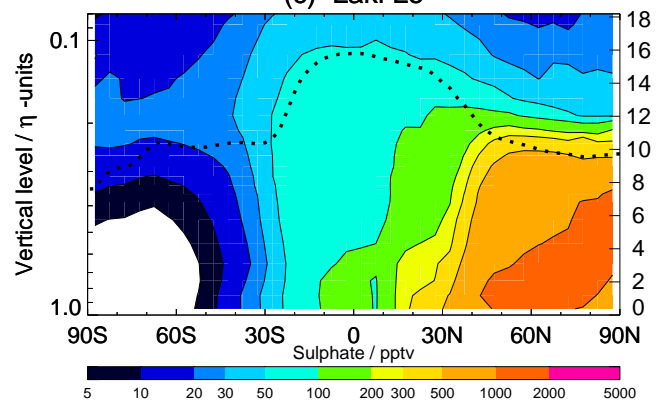

(e) Laki Hi_pulse

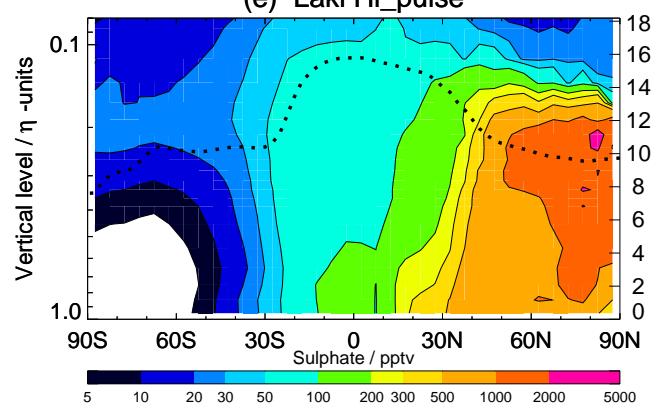

(b) 1860

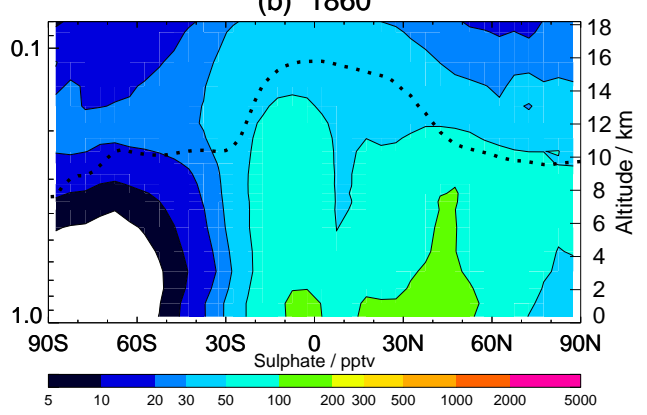

(d) Laki Hi

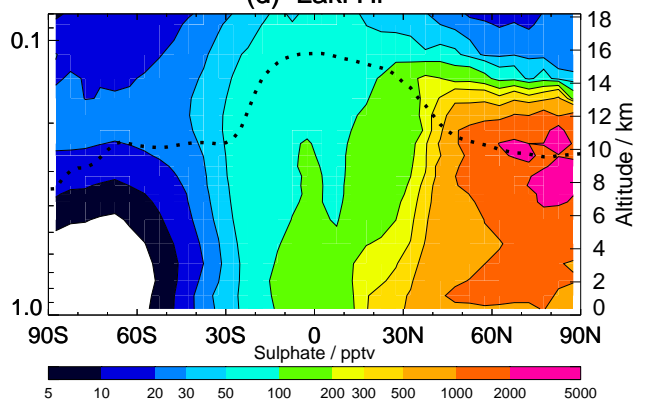

Fig. 5. Zonal, June-July-August (JJA) mean $\mathrm{SO}_{4}$ concentrations (ppbv) for: (a) 1990; (b) 1860; (c) Laki Lo; (d) Laki Hi; and (e) Laki Hi_pulse. The dotted line is the tropopause.

\subsection{Comparison of the 1990 scenario with observations}

Figure 7 shows monthly mean modelled $\mathrm{SO}_{2}$ and sulphate from the 1990 experiment, and observed values from three European stations: Spitzbergen in the Arctic; Tange in central Europe; and Roquetas in SW Europe (Hjellbrekke et al., 1996). The figure shows model results for 17 months (the full run length, excluding the first 4 months spin-up), with 12 months of observations. Differences in the intitial and final 5 months indicate interannual variability arising from the meteorology, which is quite large for these relatively short-lived species. At all three sites, the magnitudes and seasonal cycle of sulphate and $\mathrm{SO}_{2}$ are reasonably reproduced, although $\mathrm{SO}_{2}$ is slightly less well modelled. Over central Europe, $\mathrm{SO}_{2}$ is over-estimated by the model, typically by a factor of over two. At Spitzbergen and Roquetas, the $\mathrm{SO}_{2}$ cycle is modelled better, but there are significant differences in several months. These problems are probably related to the resolution of the model, and in particular the coarse $\left(5^{\circ} \times 5^{\circ}\right)$ emissions grid over Europe. In addition, the use of meteorological data from a climate model, rather than analysed data, will mean that cloud and precipitation distributions, winds and boundary layer heights may not be representative of the conditions prevailing when observations were taken. These factors, combined with the short lifetime of $\mathrm{SO}_{2}$, make it a particularly difficult gas to compare with measurements. Despite these problems with $\mathrm{SO}_{2}$, which are typical of models (Restad et al., 1998; Koch et al., 1999), the reasonable agreement with sulphate is encouraging, and gives us confidence in the results. A more detailed validation of sulphur species in the model is presented by Derwent et al. (2003).

Also plotted on Fig. 7 are the modelled results from the background pre-industrial run, and the Laki scenarios, with the results scaled to fit on the plots. These show the major influence of the eruption on European air quality during the summer of 1783, and the likely impact of a similar eruption today. 


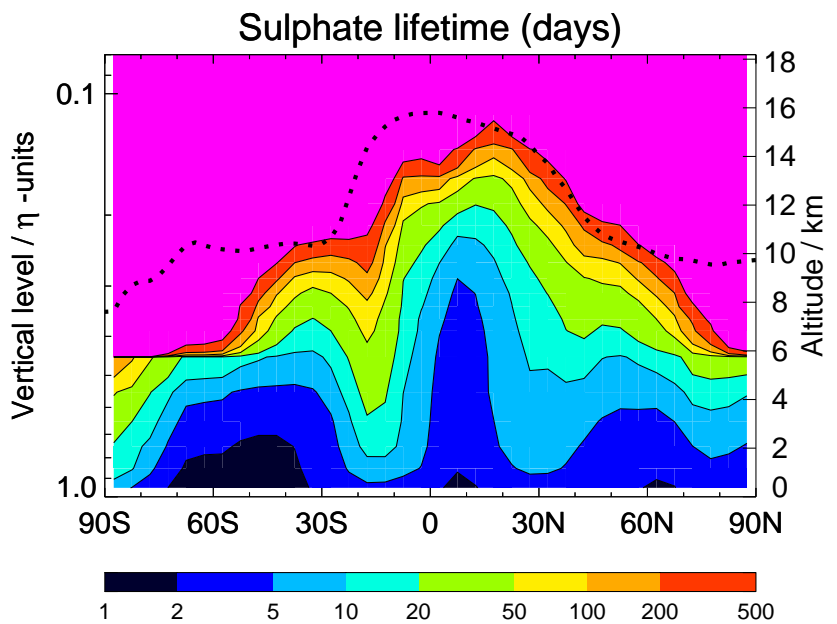

Fig. 6. Zonal, June-July-August (JJA) mean $\mathrm{SO}_{4}$ lifetime (days) for the five scenarios (all scenarios are the same). The dotted line is the tropopause.

\subsection{Temporal evolution of the Laki impact}

Given the relatively short lifetimes of both $\mathrm{SO}_{2}$ and sulphate in the troposphere, the temporal evolution of the Laki eruption impact is mainly controlled by the variation with time of the emissions. Figure 8 shows the evolution of the zonal mean sulphate from Laki in the model, for the surface, UT, and LS. The impact of the eruption is essentially restricted to the NH, with only a small amount of transport into the $\mathrm{SH}$ in the LS. Sulphate peaks in the second month of the eruption (July). In the lower troposphere, as soon as the emissions shut off in February, the anomaly ceases. This is also mainly true of the UT/LS, although the longer sulphate lifetime in this region allows a minor perturbation to persist for a few months.

\subsection{Sulphur deposition}

Annual total sulphur deposition fields for the five cases are shown in Fig. 9. Total sulphur deposition is the sum of wet and dry deposition of $\mathrm{SO}_{2}, \mathrm{H}_{2} \mathrm{SO}_{4}$ and $\left(\mathrm{NH}_{4}\right)_{2} \mathrm{SO}_{4}$. Annual totals for each process are given in Table 3. Much of the sulphur is dry deposited as $\mathrm{SO}_{2}$ gas; wet deposition of $\mathrm{SO}_{2}$ is unlikely to be distinguishable from wet deposition of $\mathrm{H}_{2} \mathrm{SO}_{4}$ aerosol. Present-day deposition peaks over the three industrial centres, but is many times higher than pre-industrial levels over much of the NH. Much of the Laki sulphur was deposited over Iceland, but large amounts also reached northern Europe and Asia. Acid deposition from sulphur and other volcanic volatiles, including $\mathrm{HF}$ and $\mathrm{HCl}$, is thought to have been responsible for much of the crop damage and livestock deaths in Iceland and the famine that followed the eruption. Away from regions of significant rainfall, environmental effects from sulphur deposition following the eruption may have been dominated by the widespread deposition of $\mathrm{SO}_{2}$ gas rather than sulphuric acid aerosol.

Figure 10 shows modelled monthly total sulphur and $\mathrm{H}_{2} \mathrm{SO}_{4}$ deposition fluxes to a grid-square in central Greenland for the Laki cases. Sulphur deposition increases by $\sim 2$ orders of magnitude above background levels at the start of the eruption, but rapidly declines to normal levels once the eruption ends. Peak modelled fluxes reach $\sim 200$ $\mathrm{mg}(\mathrm{S}) \mathrm{m}^{-2}$ month $^{-1}$. The majority ( $\sim 85 \%$ ) of the sulphur is deposited as $\mathrm{SO}_{2}$ rather than $\mathrm{H}_{2} \mathrm{SO}_{4}$. Modelled sulphur deposition to Greenland over the year following the eruption totals $360-500 \mathrm{mg}(\mathrm{S}) \mathrm{m}^{-2}$, compared to background levels of $\sim 8.6 \mathrm{mg}(\mathrm{S}) \mathrm{m}^{-2}$ in 1860 and roughly double that value in 1990. There is no strong indication in the Laki simulations of a peak in the following spring, as suggested by one ice core study (Fiacco et al., 1994). Instead, these model results support later ice-core studies (Mosley-Thompson et al., 2002) that indicate a sulphate peak in 1783 , coincident with the eruption.

Table 4 shows measured $\mathrm{H}_{2} \mathrm{SO}_{4}$ accumulations in several Greenland ice cores (Clausen and Hammer, 1988; Zielinski, 1995; Clausen et al., 1997; Mosley-Thompson et al., 2002), compared to our model results. Modelled background values, and the total $\mathrm{H}_{2} \mathrm{SO}_{4}$ deposition associated with the eruption, are both in reasonable agreement with measurements. This suggests that any deposited $\mathrm{SO}_{2}$ was not oxidised to $\mathrm{SO}_{4}^{2-}$ after deposition; possibly it was re-emitted, or preserved as $\mathrm{SO}_{2}$ and just not measured by any of the techniques applied in the ice-core analyses. There is experimental evidence that $\mathrm{SO}_{2}$ deposition to snow decreases with decreasing temperature (Dasch and Cadle, 1986), and this effect is neglected in the model, so $\mathrm{SO}_{2}$ deposition to Greenland and the Arctic may have been overestimated. Any reduction in deposition (or re-emission) of $\mathrm{SO}_{2}$ to (from) snow would further enhance $\mathrm{SO}_{2}$ concentrations in the lower troposphere. Model results from the Hi_pulse case are lower than the other cases, despite using the same total emission. This gives an indication of the importance of meteorological variability in the results; because the $\mathrm{Hi}_{\text {_pulse }}$ scenario emissions are released at different times compared to the monthly mean cases, they sample different meteorology, and less of the aerosol is deposited to Greenland. Overall, the deposition fields (Fig. 9) are quite similar, but deposition at specific sites is subject to much more variability between scenarios.

\subsection{Total aerosol yield and peak atmospheric loading}

The modelled global atmospheric burden of $\mathrm{H}_{2} \mathrm{SO}_{4}$ rises from background levels of $\sim 0.2 \mathrm{Tg}(\mathrm{S})$ to $\sim 1.7 \mathrm{Tg}(\mathrm{S})$ in July, followed by an approximately exponential decay back to normal values over the next 12 months (Fig. 11). In the Laki $\mathrm{Hi}$ cases, the decay is slower, and slightly elevated levels of $\sim 0.3 \mathrm{Tg}(\mathrm{S})$ still exist after a year. The total atmospheric aerosol mass is likely to be larger by a factor (134/32), as $\mathrm{H}_{2} \mathrm{SO}_{4}$ typically exists as $\mathrm{H}_{2} \mathrm{SO}_{4} \cdot 2 \mathrm{H}_{2} \mathrm{O}$. This indicates a 

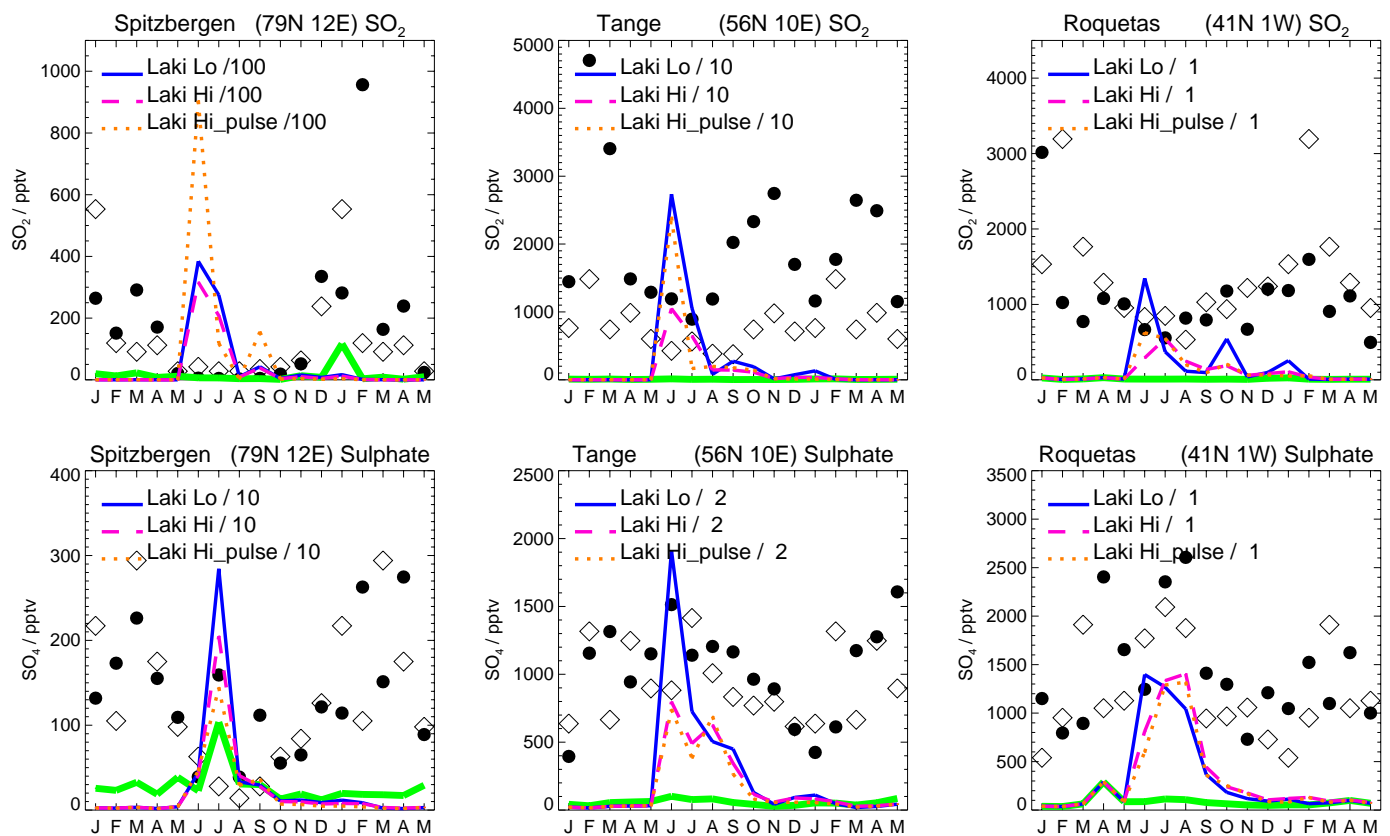

Fig. 7. Comparison of 1990 modelled surface $\mathrm{SO}_{2}$ and $\mathrm{SO}_{4}(\bullet)$ with recent observations $(\diamond)$ (Hjellbrekke et al., 1996) at 3 European sites. The plot extends over 17 months of model results; observations are repeated for the second year. Also shown are results from the 1860 scenario (thick green line), and the three Laki scenarios (solid blue, dashed magenta and dotted brown lines), reduced by up to a factor of 100 to fit on the plots.

Table 4. Modelled and measured $\mathrm{SO}_{4}^{2-}$ depositions to Greenland Ice, for the Laki eruption, and background levels at the time of the eruption

\begin{tabular}{|c|c|c|}
\hline & $\begin{array}{c}\text { Background } \mathrm{H}_{2} \mathrm{SO}_{4} \\
{\left[\mathrm{mg}(\mathrm{S}) \mathrm{m}^{-2} \mathrm{yr}^{-1}\right]}\end{array}$ & $\begin{array}{l}\text { Laki } \mathrm{H}_{2} \mathrm{SO}_{4} \\
{\left[\mathrm{mg}(\mathrm{S}) \mathrm{m}^{-2}\right]}\end{array}$ \\
\hline \multicolumn{3}{|l|}{ Modelled (this work) } \\
\hline Laki Hi & 5.0 & 63 \\
\hline Laki Lo & 5.0 & 65 \\
\hline Laki Hi_pulse & 5.0 & 35 \\
\hline \multicolumn{3}{|l|}{ Measured } \\
\hline \multirow{3}{*}{$\begin{array}{l}\text { Clausen and Hammer }(1988) \text { (Table IV) } \\
\left(\mathrm{H}^{+} / \mathrm{ECM} \text { technique: } 11 \text { cores }\right) \\
\left(\mathrm{SO}_{4}^{2-} \text { technique: } 4 \text { cores }\right)\end{array}$} & & \\
\hline & $8.6 \pm 4.4$ & $56 \pm 23$ \\
\hline & $2.9 \pm 0.7$ & $55 \pm 5$ \\
\hline \multicolumn{3}{|l|}{ Zielinski (1995) (Table 6) } \\
\hline GISP2 (SO ${ }_{4}^{2-}$ technique $)$ & - & 19 \\
\hline \multicolumn{3}{|l|}{ Clausen et al. (1997) (Table 3) } \\
\hline DYE 3 (ECM technique) & 7.9 & 33 \\
\hline GRIP (ECM technique) & 4.3 & 23 \\
\hline \multicolumn{3}{|l|}{ Mosley-Thompson et al. (2002) } \\
\hline PARCA cores: range from 6 cores & - & $18-107$ \\
\hline
\end{tabular}



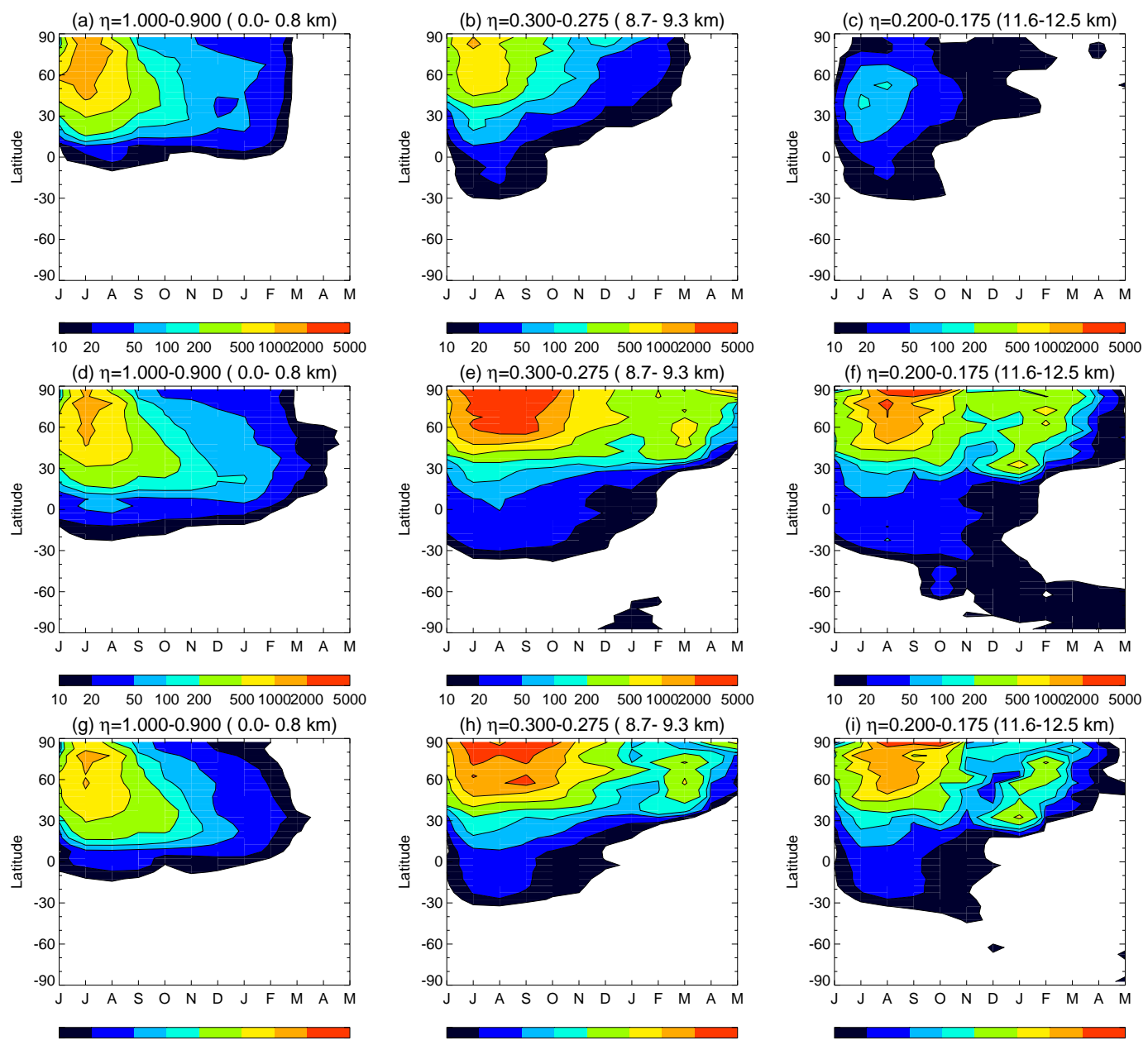

Fig. 8. Temporal evolution of the zonal mean Laki $\mathrm{SO}_{4}$ (pptv) for Laki Lo (a-c), Laki Hi (d-f) and Laki Hi_pulse (g-i) at three levels in the model: the surface (a, d, g); the upper troposphere (b, e, h); and the lower stratosphere (c, f, i). Background 1860 levels have been subtracted.

peak global aerosol loading of $\sim 7 \mathrm{Tg}$, similar to the estimate of Stothers (1996).

Table 5 compares our model results with previous estimates of the total aerosol yield from Laki, either derived from Greenland ice core deposits (Clausen and Hammer, 1988; Zielinski, 1995; Clausen et al., 1997), or from observed optical depths (Stothers, 1996), or inferred from emissions (Thordarson et al., 1996; Thordarson and Self, 2003). The largest estimate is from Clausen and Hammer (1988) who used ice core measurements together with measured deposition of nuclear bomb products from a high Northern latitude test of known magnitude, to infer an atmospheric aerosol loading for Laki of $91 \mathrm{Tg}(\mathrm{S})$.

Our work indicates total aerosol production from Laki of 17-22 $\mathrm{Tg}(\mathrm{S})$. Due to the relatively short atmospheric lifetime of the aerosol, its peak burden is only $\sim 1.7 \mathrm{Tg}(\mathrm{S})$ (Fig. 11), as discussed above. Our modelled estimate of deposition to Greenland is similar to Clausen and Hammer (1988); the larger estimate of aerosol yield by these authors occurs mainly because Laki was much closer to Greenland than the nuclear test, and added material to the atmosphere at lower altitudes. The results presented here suggest that inversion of nuclear bomb product deposition to ice cores is not a good method for calculating volcanic aerosol yields if the eruption is relatively close to the deposition site, or if material is not injected at similar heights to the nuclear explosion (mid-stratosphere).

\subsection{Missing feedbacks and other uncertainties}

The model results presented here represent a new approach compared with previous assessments of the atmospheric impact from the Laki eruption. However, there remain large uncertainties in the results. Several potentially important couplings have not been included in the simulations described here. The modelled aerosol does not influence the model photolysis rates, which are important in determining oxidant concentrations (Tie et al., 2001). There is also no dynamical feedback of the aerosol on the model's meteorology, either 
(a) 1990

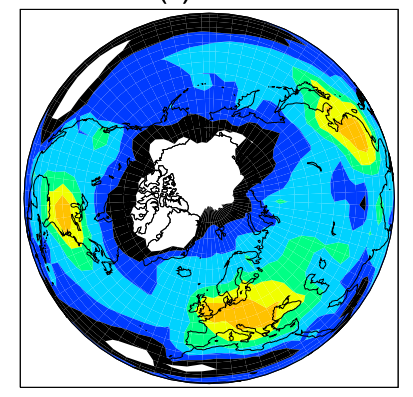

Total S deposition / $\mathrm{g}(\mathrm{S}) \mathrm{m}^{-2} \mathrm{yr}^{-1}$

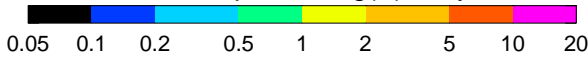

(c) Laki Lo

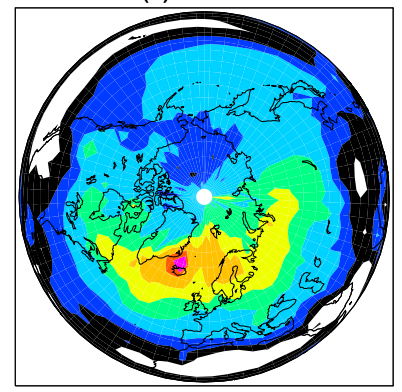

Total S deposition / $\mathrm{g}(\mathrm{S}) \mathrm{m}^{-2} \mathrm{yr}^{-1}$

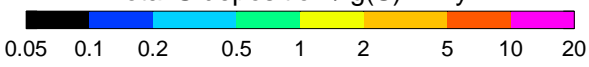

(e) Laki Hi_pulse

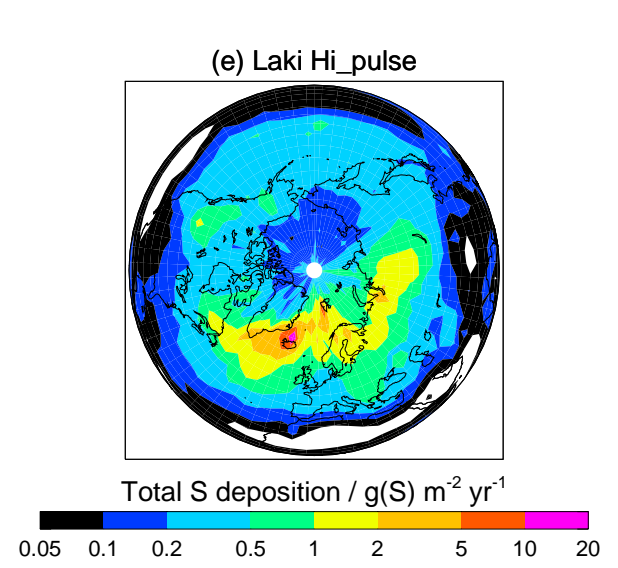

Total S deposition / $\mathrm{g}(\mathrm{S}) \mathrm{m}^{-2} \mathrm{yr}^{-1}$

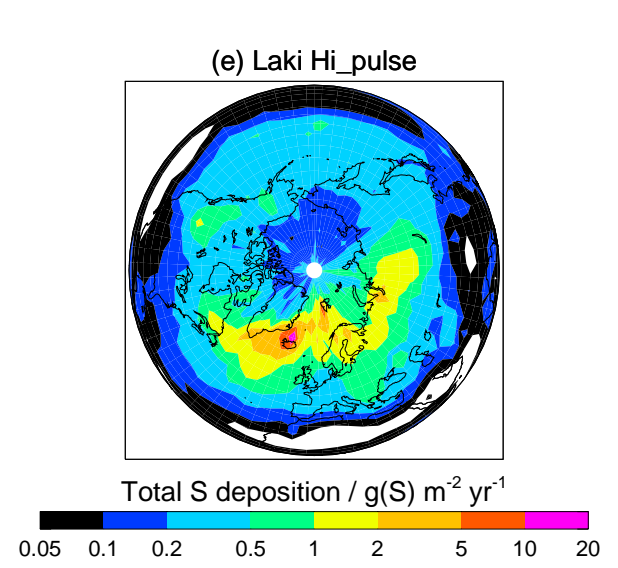

(b) 1860

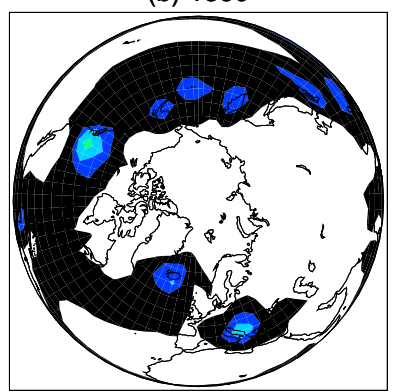

Total S deposition / $\mathrm{g}(\mathrm{S}) \mathrm{m}^{-2} \mathrm{yr}^{-1}$

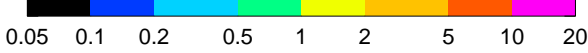

(d) Laki Hi

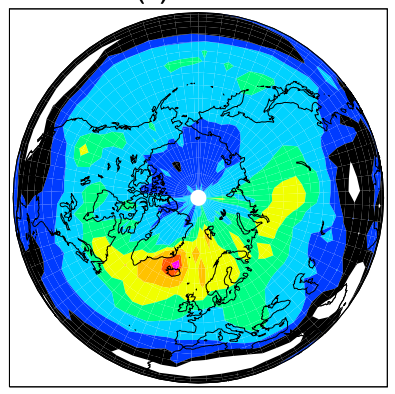

Total S deposition / $\mathrm{g}(\mathrm{S}) \mathrm{m}^{-2} \mathrm{yr}^{-1}$

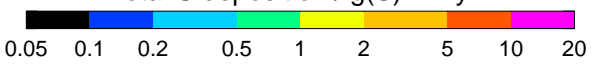

Fig. 9. Northern Hemisphere annual mean total sulphur deposition fluxes (g(S) $\mathrm{m}^{-2} \mathrm{yr}^{-1}$ ) for: (a) 1990; (b) 1860; (c) Laki Lo; (d) Laki Hi; and (e) Laki Hi_pulse.

through the radiation code or through the cloud scheme. However, the climatic impact of the aerosol is examined using a decoupled methodology in the second part of this work (Highwood and Stevenson, 2003). Possibly the largest uncertainty associated with the Laki eruption is the height profile of the $\mathrm{SO}_{2}$ emissions. We have used two different profiles in an attempt to span a wide range of possibilities. Nevertheless, the $\mathrm{SO}_{2}$ could have been predominantly emitted at either lower or higher altitudes than used here. Higher level emissions may have been oxidised more efficiently and remained airborne for a longer period than calculated here. For lower altitude emissions the reverse would be true. The estimated emissions only represent a minimum total magnitude. On the other hand, no attempt has been made to model chemistry in the volcanic plume, and there may have been significant removal of sulphur from the system, for example by uptake on ash particles. The broadly similar conclusions reached for both the Laki Lo and Laki Hi scenarios suggests 
Table 5. Estimates of the total aerosol yield and peak global aerosol loading of the atmosphere from the Laki eruption

\begin{tabular}{lcc}
\hline & $\begin{array}{c}\text { Total aerosol yield } \\
{[\operatorname{Tg}(\mathrm{S})]}\end{array}$ & $\begin{array}{c}\text { Peak aerosol loading } \\
{[\operatorname{Tg}(\mathrm{S})]}\end{array}$ \\
\hline This work & & \\
& 17 & 1.4 \\
Laki Lo & 22 & 1.7 \\
Laki Hi & 18 & 1.6 \\
Laki Hi_pulse & 91 & - \\
Clausen and Hammer (1988) & $11-14$ & - \\
Zielinski (1995) & 49 & - \\
Stothers (1996) & $33-50$ & - \\
Clausen et al. (1997) & 65 & \\
Thordarson and Self (2003) & & - \\
\hline
\end{tabular}

that the vertical profile may not be a crucial factor. Introduction of eruption episodicity modulates the results somewhat, but because of the similarity between the lifetimes of $\mathrm{SO}_{2}$ and $\mathrm{SO}_{4}$, and the lengths of the episodes and repose periods (days-weeks), this does not significantly affect the results. The lack of aerosol microphysics in the model introduces further uncertainty, particularly concerning aerosol removal. No account of aerosol sedimentation is included, but this is probably only a significant process in the stratosphere, and in areas where vertical transport is very slow. The local lifetime of 67 days in the LS is determined by transport; any sedimentation will tend to reduce this lifetime.

Thordarson and Self (2003) estimated that about $230 \mathrm{Tg}$ of magmatic water vapour was released with the $\mathrm{SO}_{2}$, and suggested that this would be more than enough to oxidise the $\mathrm{SO}_{2}$ to aerosol. However, $\mathrm{SO}_{2}$ does not react directly with water to produce sulphuric acid. Water is an important precursor of the two major $\mathrm{SO}_{2}$ oxidants, $\mathrm{OH}$ and $\mathrm{H}_{2} \mathrm{O}_{2}$, and levels of these oxidants can be expected to increase as water vapour levels increase. However, there is a large amount of water readily available in the atmosphere, and ambient temperatures will limit the increase in water vapour, such that humidity cannot exceed $100 \%$. Assuming that the plume rapidly comes into thermal equilibrium with the environment, and a conservative estimate of $50 \%$ humidity in the background air above Iceland, then water vapour levels will, at most, double, with perhaps similar increases in oxidant levels, and hence sulphate production. However, to generate $\mathrm{OH}, \mathrm{UV}$ radiation and ozone are also required, in order to generate excited oxygen atoms $\left(\mathrm{O}\left({ }^{1} \mathrm{D}\right)\right)$ :

$\mathrm{O}_{3}+h v \longrightarrow \mathrm{O}\left({ }^{1} \mathrm{D}\right)+\mathrm{O}_{2}$

$\mathrm{O}\left({ }^{1} \mathrm{D}\right)+\mathrm{H}_{2} \mathrm{O} \longrightarrow 2 \mathrm{OH}$
As $\mathrm{OH}$ concentrations rise, so will concentrations of the hydroperoxyl radical $\left(\mathrm{HO}_{2}\right)$. At high radical concentrations, radical loss rates are proportional to $\left[\mathrm{HO}_{\mathrm{x}}\right]^{2}\left(\mathrm{HO}_{\mathrm{x}}=\mathrm{OH}+\right.$ $\mathrm{HO}_{2}$ ), and this acts as a strong buffer on radical concentrations rising further. Any rise in $\mathrm{OH}$ will therefore be limited by the availability of $\mathrm{O}_{3}$, sunlight, and radical selfdestruction. The importance of magmatic water will also decrease as the plume mixes with the background atmosphere, which is likely to occur on timescales of hours to days, much less than the chemical lifetime of $\mathrm{SO}_{2}$ in the UT/LS (12-25 days). Overall, we suspect that magmatic water vapour will locally increase oxidant levels (and hence sulphate production), but will have a limited impact at larger scales. The neglect of magmatic water vapour is not expected to have a major influence on our results.

Another possible impact on atmospheric composition that we have neglected involves the effect of sulphur deposition from Laki upon the global source of methane, which may have been significantly reduced. Recent findings show that levels of sulphur deposition comparable to those reported here can significantly reduce $\mathrm{CH}_{4}$ emissions from natural freshwater wetlands and tundra (Gauci et al., 2002). An increase in the sulphate supply to these areas is thought to stimulate microbial competition in anaerobic soils by enabling sulphate-reducing bacteria to out-compete methaneproducing micro-organisms for available substrates (Lovely and Klug, 1983). Wetlands and tundra formed the major preindustrial $\mathrm{CH}_{4}$ sources, with the highest concentration located in mid to high northern latitudes (Matthews and Fung, 1987). It is likely that many of these $\mathrm{CH}_{4}$ sources, and in particular those in Scandinavia and Siberia, will have been sufficiently impacted by the sulphur deposited from Laki for atmospheric $\mathrm{CH}_{4}$ levels to have been reduced. These effects 


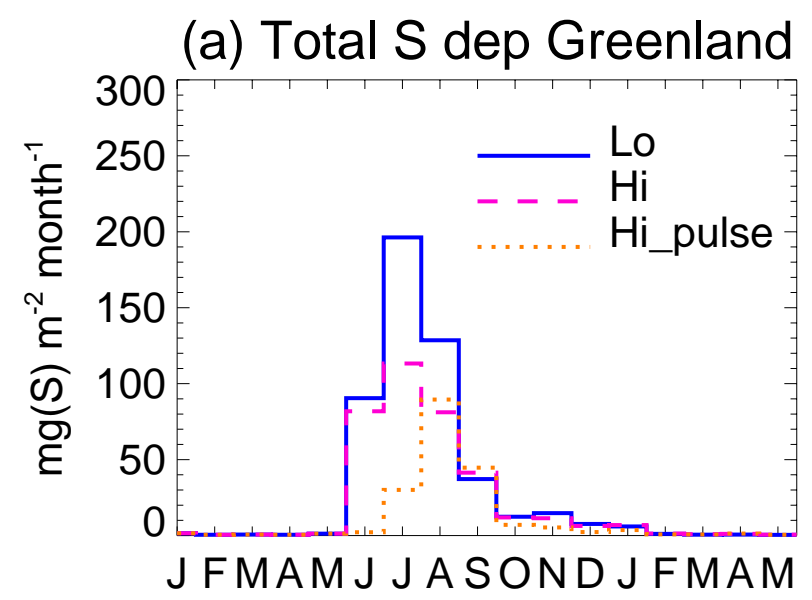

(b) $\mathrm{H}_{2} \mathrm{SO}_{4}$ dep Greenland

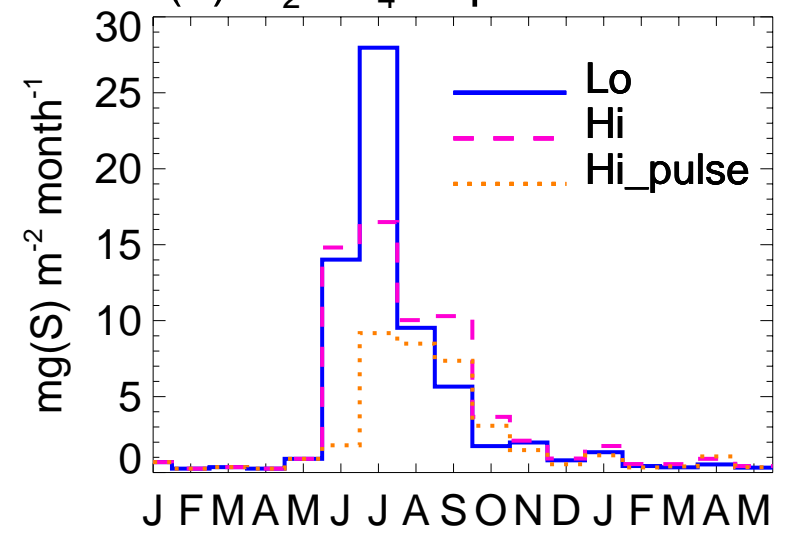

Fig. 10. Simulated monthly (a) total sulphur and (b) $\mathrm{H}_{2} \mathrm{SO}_{4}$ deposition fluxes $\left(\mathrm{mg}(\mathrm{S}) \mathrm{m}^{-2}\right.$ month $\left.^{-1}\right)$ to central Greenland, for the three Laki scenarios.

may have continued well beyond the period of the eruption, possibly for several years. Perturbations to atmospheric $\mathrm{CH}_{4}$ are known to decay with decadal timescales (Prather, 1994; Derwent et al, 2001), so this process could introduce a relatively long-lived climate impact. Further investigation of these mechanisms and uncertainties is beyond the scope of this paper and requires further research.

\subsection{Implications for similar eruptions}

Eruptions similar to Laki have a return period of a few hundred years, for example the Eldgjá eruption from Iceland in the tenth century (Stothers, 1998). A similar eruption today would add to anthropogenic pollution, and could pose major air quality problems in terms of $\mathrm{SO}_{2}$ and particle concentrations (Fig. 7). It may also provide an opportunity to observe the troposphere under a very high aerosol load, possibly revealing details about the direct and indirect affects of aerosols, an area of high uncertainty in models of future climate change (Penner et al., 2001).

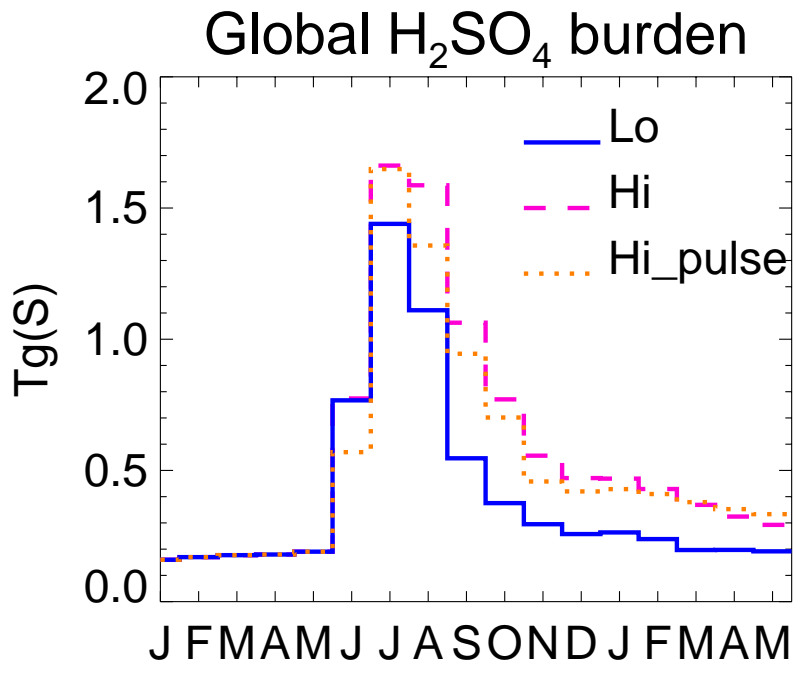

Fig. 11. Monthly global $\mathrm{H}_{2} \mathrm{SO}_{4}$ burden $\left(\mathrm{Tg}\left(\mathrm{H}_{2} \mathrm{SO}_{4}\right)\right)$, for the three Laki scenarios.

These results also have implications for the similar, but much larger, flood basalt eruptions of the geological past, e.g. the Roza eruption (Thordarson and Self, 1996). Previous studies of these have generally assumed that all of the $\mathrm{SO}_{2}$ released went on to form aerosol, and hence affect climate. At much larger $\mathrm{SO}_{2}$ loadings than Laki, oxidant depletion in the troposphere is likely to be even more intense (although this may depend on the latitude and season of the eruption), and an even higher proportion of the $\mathrm{SO}_{2}$ will be deposited rather than form aerosol. The environmental effects of widespread $\mathrm{SO}_{2}$ deposition (Grattan, 1998) may outweigh climate perturbations, and may also affect temperature proxies such as tree-rings (Pearson et al., 2002). Volcanic aerosols formed in the troposphere or LS should not be assumed to have atmospheric residence times similar to the $1991 \mathrm{Mt}$. Pinatubo aerosol (1-2 years), which was injected to heights of 20-25 $\mathrm{km}$. A recent study by Blake (2003) suggests that historical explosive eruptions only generated a significant climate impact if they injected material to altitudes of 1.5 times the local tropopause height. At these altitudes, the aerosol will have a residence time similar to the Mt. Pinatubo aerosol, but at lower heights, aerosol will be removed more rapidly.

This modelling study has some deficiencies in its treatment of the LS (e.g. lack of complete stratospheric chemistry), however it suggests that we should exercise caution when considering the climate effects of eruptions that only reach the LS, as aerosol residence times in this region may not be sufficiently long to significantly perturb climate. On the other hand, if the eruption is long enough in duration, then sustained $\mathrm{SO}_{2}$ emissions may generate tropospheric aerosol with potential to affect climate, in just the same way as present-day anthropogenic $\mathrm{SO}_{2}$ emissions. 


\section{Conclusions}

Simulations of the global tropospheric sulphur cycle with a 3-D chemistry-transport model have been performed for 1990, 1860, and during the 1783-1784 Laki eruption. Sulphate and $\mathrm{SO}_{2}$ budgets and concentrations from the presentday case compare well with observations and other state-ofthe-art models. The model allows the fate of the $\mathrm{SO}_{2}$ emitted by Laki to be analysed in detail. Peak zonal mean concentrations during the summer of 1783 are $\sim 20$ ppbv $\mathrm{SO}_{2}$ (cf. 0.1 and $0.5 \mathrm{ppbv}$ in 1860 and 1990) and $\sim 2 \mathrm{ppbv} \mathrm{SO}_{4}^{2-}$ (cf. 0.1 and $1 \mathrm{ppbv}$ in 1860 and 1990). About $70 \%$ of the volcanic $\mathrm{SO}_{2}$ is deposited before it has the chance to form aerosol. The remaining $\mathrm{SO}_{2}$ is oxidised by $\mathrm{OH}$ in the gas-phase and mainly by $\mathrm{H}_{2} \mathrm{O}_{2}$ in the aqueous-phase, causing a significant depletion in both of these oxidants. This oxidant depletion significantly increases the local lifetime of $\mathrm{SO}_{2}$, and the mean lifetime of Laki $\mathrm{SO}_{2}$ is 9-20 days (cf. 1.6 and 1.1 days in 1860 and 1990). The model generates a total of 17$22 \mathrm{Tg}(\mathrm{S})$ of sulphuric acid aerosol from the eruption, with a mean lifetime of 6-10 days (cf. 5.8 and 5.4 days in 1860 and 1990). The peak total aerosol loading of the atmosphere is $\sim 1.7 \mathrm{Tg}(\mathrm{S})$, generally much lower than previous estimates; this compares with burdens of 0.28 and $0.81 \mathrm{Tg}(\mathrm{S})$ in 1860 and 1990. In the lower stratosphere, aerosol has a longer lifetime ( $\sim 2$ months), but most of the aerosol generated has been removed by the end of the eruption. Simulated deposition of $\mathrm{H}_{2} \mathrm{SO}_{4}$ to central Greenland is in reasonable agreement with measurements, and approximately coincides with the eruption. These results have implications for large-scale volcanic eruptions that add large quantities of $\mathrm{SO}_{2}$ to the troposphere and lower stratosphere. Some previous studies have wrongly assumed that most of this $\mathrm{SO}_{2}$ will form aerosol with relatively long atmospheric residence times. This study suggests that much of the $\mathrm{SO}_{2}$ will be deposited before oxidation, and that aerosol residence times will be of the order of weeks, rather than the commonly assumed 1-2 years, which is more appropriate for large explosive eruptions that add material to the mid-stratosphere.

Acknowledgements. We would like to thank T. Crowley and E. Mosley-Thompson for providing advice and ice core data. The manuscript was improved by reviews by F. Dentener and C. Timmreck. DSS was funded by a NERC UGAMP fellowship and a NERC/Environment Agency Advanced Fellowship (P4-F02). EJH was partly funded by a NERC fellowship. CEJ, WJC and RGD thank DETR for support through contracts EPG 1/3/164 and PECD $7 / 12 / 37$.

\section{References}

Adams, P. J., Seinfeld, J. H., and Koch, D. M.: Global concentrations of tropospheric sulphate, nitrate, and ammonium aerosol simulated in a general circulation model, J. Geophys. Res., 104, 13 791-13 823, 1999.
Andres, R. J. and Kasgnoc, A. D.: A time-averaged inventory of subaerial volcanic sulfur emissions, J.Geophys. Res., 103, 25 251-25 261, 1998.

Blake, $\mathrm{S}$.: Correlations between eruption magnitude, $\mathrm{SO}_{2}$ yield, and surface cooling, in: Volcanic degassing: Experiments, Models, Observations and Impacts, eds. Oppenhiemer, C., Pyle, D., and Barclay, J., Geol. Soc. Spec. Pub., in press, 2003.

Brasseur, G. P., Kiehl, J. t., Müller, J. F., Schneider, T., Granier, C., Tie, X. X., and Hauglustaine, D.: Past and future changes in global tropospheric ozone: Impact on radiative forcing, Geophys. Res. Lett., 25, 3807-3810, 1998.

Clausen, H. B. and Hammer, C. U.: The Laki and Tambora eruptions as revealed in Greenland ice cores from 11 locations, Annals of Glaciology, 10, 16-22, 1988.

Clausen, H. B., Hammer, C. U., Hvidberg, C. S., Dahl-Jensen, D., Steffensen, J. P., Kipfstuhl, J., and Legrand, M.: A comparison of the volcanic records over the past 4000 years from the Greeland Ice Core Project and Dye 3 Greenland ice cores, J. Geophys. Res., 102, 26 707-26723, 1997.

Collins, W. J., Stevenson, D. S., Johnson, C. E., and Derwent, R. G.: Tropospheric ozone in a global-scale 3-D Lagrangian model and its response to $\mathrm{NO}_{\mathrm{x}}$ emission controls, J. Atmos. Chem., 26, 223-274, 1997.

Collins, W. J., Stevenson, D. S., Johnson, C. E., and Derwent, R. G.: A simulation of long-range transport of CFCs in the troposphere using a 3-D Global Lagrangian model with 6-hourly meteorological fields, Air Pollution Modeling and Its Application XII, 227-235, 1998.

Collins, W. J., Stevenson, D. S., Johnson, C. E., and Derwent, R. G.: Role of convection in determining the budget of odd hydrogen in the upper troposphere, J. Geophys. Res., 104, 26 927-26941, 1999.

Collins, W. J., Derwent, R. G., Johnson, C. E., and Stevenson, D. S.: The impact of human activities upon the photochemical production and destruction of tropospheric ozone, Q. J. R. Meteorol. Soc., 126, 1925-1952, 2000.

Cooke W. F. and Wilson, J. J. N.: A global black carbon aerosol model, J. Geophys. Res., 101, 19395-19409, 1996.

Dasch, J. M. and Cadle, S. H.: Dry deposition to snow in an urban area, Water Air and Soil Pollution, 29(3), 297-308, 1986

Demaree, G. R., Ogilvie, A. E. J., and Zhang, D.: Further documentary evidence of northern hemispheric coverage of the great dry fog of 1783, Climatic Change, 39, 727-730, 1998.

Dentener, F. J. and Crutzen, P. J.: Reaction of $\mathrm{N}_{2} \mathrm{O}_{5}$ on tropospheric aerosols: Impact on the global distribution of $\mathrm{NO}_{\mathrm{x}}, \mathrm{O}_{3}$ and $\mathrm{OH}$, J. Geophys. Res., 98, 7149-7163, 1993.

Derwent, R. G., Collins, W. J., Johnson, C. E., and Stevenson, D. S.: Transient behaviour of tropospheric ozone precursors in a global 3-D CTM and their indirect greenhouse effects, Climatic Change, 49, 463-487, 2001.

Derwent, R. G., Collins, W. J., Jenkin, M. E., Johnson, C. E., and Stevenson, D. S.: The global distribution of secondary particulate matter in a 3-D Lagrangian chemistry transport model, J. Atmos. Chem., 44, 57-95, 2003.

Erisman, J. W. and Baldocchi, D.: Modelling dry deposition of $\mathrm{SO}_{2}$, Tellus, 46B, 159-171, 1994.

Fiacco, R. J., Thordarson, T., Germani, M. S., et al.: Atmospheric aerosol loading and transport due to the 1783-1784 Laki eruption in Iceland, interpreted from ash particles and acidity in the GISP2 ice core, Quaternary Research, 42, 231-240, 1994. 
Gauci, V., Dise, N. B., and Fowler, D.: Controls on suppression of methane flux from a peat bog subjected to simulated acid rain sulfate deposition, Glob. Biogeochem. Cycles, 16, 1, 10.1029/2000GB001370, 2002.

Graf, H.-F., Feichter, J., and Langmann, B.: Volcanic sulfur emission: Estimates of source strength and its contribution to the global sulfate distribution, J. Geophys. Res., 102, 10727-10 738, 1997.

Grattan, J. P.: The distal impact of volcanic gases and aerosols in Europe: a review of the 1783 Laki fissure eruption and environmental vulnerability in the late 20th century, Geological Society Special Publication, 15, 9, 7-53, 1998.

Grattan, J. P. and Pyatt, F. B.: Volcanic eruption dry fogs and the European palaeoenvironmental record: localised phenomena or hemispheric impacts? Global and Planetary Change, 21, 173$179,1999$.

Guenther, A., Hewitt, C., Erickson, D., et al.: A global model of natural volatile organic compound emissions, J. Geophys. Res., 100, 8873-8892, 1995.

Hauglustaine, D. A. and Brasseur, G. P.: Evolution of tropospheric ozone under anthropogenic acitvities and associated radiative forcing of climate, J. Geophys. Res., 106, 32 337-32 360, 2001.

Highwood, E. J. and Stevenson, D. S.: Atmospheric impact of the 1783-1784 Laki eruption: Part 2 Climatic effect of sulphate aerosol, Atm. Chem. Phys. Disc., 3, 1599-1629, 2003.

Hjellbrekke, A.-G., Schaug, J., and Skjelmoen, J. E.: EMEP Data Report 1994, Part 1: Annual summaries, EMEP/CCC Report 4/96, Norwegian Institute for Air Research, Kjeller, Norway, 1996.

Isaksen, I., Jackman, C., Baughcum, S., et al.: Modeling the chemical composition of the future atmosphere, in: Aviation and the Global Atmosphere, Penner, J. E. et al. (Eds), Cambridge University Press, Cambridge, UK and New York, NY, USA, 373, 1999.

Jenkin, M. E., Clement, C. F., and Ford, I. J.: Gasto-particle conversion pathways, AEA Technology Report, AEA/RAMP/20010010/001/Issue 1, Culham Laboratory, Oxfordshire, UK, 1996.

Johns, T. C., Carnell, R. E., Crossley, J. F., et al.: The Second Hadley Centre Coupled Ocean-Atmosphere GCM: Model Description, Spinup and Validation, Clim. Dyn., 13, 103-134, 1997.

Johnson, C. E., Stevenson, D. S., Collins, W. J., and Derwent, R. G.: Role of climate feedback on methane and ozone studied with a coupled Ocean-Atmosphere-Chemistry model, Geophys. Res. Lett., 28, 1723-1726, 2001.

Kanakidou, M., Dentener, F. J., Brasseur, G. P., et al.: 3-D global simulations of tropospheric CO distributions - Results of the GIM/IGAC intercomparison 1997 exercise, Chemosphere: Global Change Science, 1, 263-282, 1999a.

Kanakidou, M., Dentener, F. J., Brasseur, G. P., et al.: 3-D global simulations of tropospheric chemistry with focus on ozone distributions, Eur. Comm. Rep., EUR18842, 1999 b.

Kington, J. A.: Historical daily synoptic weather maps from the 1780s, J. Meteorol., 3, 65-70, 1978.

Kington, J. A.: The weather of the 1780s over Europe, Cambridge University Press, Cambridge, England, 164, 1988.

Koch, D. M., Jacob, D., Tegen, I., Rind, D., and Chin, M.: Tropospheric sulfur simulation and sulfate direct radiative forcing in the Goddard Institute for Space Studies general circulation model, J. Geophys. Res., 104, 23 799-23 822, 1999.
Laj, P., Drummey, S. M., Spencer, M. J., et al.: Depletion of $\mathrm{H}_{2} \mathrm{O}_{2}$ in a Greenland ice core: implications for oxidation of volcanic $\mathrm{SO}_{2}$, Nature, 346, 45-48, 1990.

Langner, J. and Rodhe, H.: A global three-dimensional model of the tropospheric sulphur cycle, J. Atmos. Chem., , 13, 225-263, 1991.

Li, D. and Shine, K. P.: A 4-D ozone climatology for UGAMP models, UGAMP internal report No. 35, 19, Dept. Meteorology, Univ. Reading, UK, 1995.

Lovely, D. R. and Klug, M. A.: Sulfate reducers can outcompete methanogens at freshwater sulfate concentrations, Appl. Environ. Microbiol., 45, 1, 187-192, 1983.

Matthews, E. and Fung, I.: $\mathrm{CH}_{4}$ emissions from natural wetlands: Global distribution, area and environmental characteristics of sources, Glob. Biogeochem. Cycles, 1, 1, 61-86, 1987.

Mickley, L. J., Murti, P. P., Jacob, D. J., Logan, J. A., Koch, D. M., and Rind, D.: Radiative forcing from tropospheric ozone calculated with a unified chemistry-climate model, J. Geophys. Res., 104, 30 153-30 172, 1999.

Minnis, P., Harrison, E. F., Stowe, L. L., et al.: Radiative climate forcing by the Mount Pinatubo eruption, Science, 259, 14111415, 1993.

Mosley-Thompson, E., Mashiotta, T. A., and Thompson, L. G.: Ice core records of late Holocene volcanism: Contributions from the Greenland PARCA cores, Volcanism and the Earth's Atmosphere, AGU Chapman Conference proceedings, 2002.

Olivier, J. G. J., Bouwman, A. F., van der Maas, C. W. M., et al. Description of EDGAR Version 2.0, RIVM report No. 771060 002, RIVM, Bilthoven, 1996.

Olson, J., Prather, M., Berntsen, T., et al.: Results from the Intergovernmental Panel on Climatic Change photochemical model intercomparison (PHOTOCOMP), J. Geophys. Res., 102, 59795991, 1997.

Ortlieb, L. and Machare, J.: Former El Nino events - records from Western South America Global Planetary Change, 7, 1-3, 181202, 1993.

Pearson, C., Manning, S., Coleman, M., and Jarvis, K.: Volcanic eruptions, tree rings and multielemental chemistry: In search of an absolute date for volcanic eruptions of the prehistoric, Volcanism and the Earth's Atmosphere, AGU Chapman Conference proceedings, 2002.

Penner, J. E., Atherton, C. S., Dignon, J., Ghan, S. J., Walton, J. J., and Hameed, S.: Global emissions and models of photochemically active compounds, in Global Atmospheric Biospheric Chemistry, edited by R. G. Prinn, 223-247, Plenum, New York, 1994.

Penner, J. E., Andreae, M., Annegarn, H., et al.: Aerosols, their direct and indirect effects, In: Climate Change 2001: The Scientific Basis. Contribution of Working Group I to the Third Assessment Report of the Intergovernmental Panel on Climate Change, Houghton, J. T. et al. (eds.), Cambridge University Press, Cambridge, UK and New York, NY, USA, 881, 2001.

Prather. M. J.: Lifetimes and eigenstates in atmospheric chemistry, Geophys. Res. Lett., 21, 801-804, 1994.

Prather, M. J., Ehhalt, D., Dentener, F., et al.: Atmospheric chemistry of greenhouse gases, In: Climate Change 2001: The Scientific Basis. Contribution of Working Group I to the Third Assessment Report of the Intergovernmental Panel on Climate Change Houghton, J. T. et al. (Eds), Cambridge University Press, Cambridge, UK and New York, NY, USA, 881, 2001. 
Price, C. and Rind, D.: A simple lightning parameterization for calculating global lightning distributions, J. Geophys. Res., 97, 9919-9933, 1992.

Rasch, P. J., Feichter, J., Law, K., et al.: A comparison of scavenging and deposition processes in global models: results from the WCRP Cambridge workshop of 1995, Tellus, 52B, 1025-1056, 2000.

Restad, K., Isaksen, I. S. A., and Berntsen, T. K.: Global distributions of sulphate in the troposphere, a three-dimensional model study, Atmos. Environ., 32, 3593-3609, 1998.

Robertson, A., Overpeck, J., Rind, D., Mosley-Thompson, E., Zielinski, G., Lean, J., Koch, D., Penner, J., Tegen, I., and Healy, R.: Hypothesized climate forcing time series for the last 500 years, J. Geophys. Res., 106, 14 783-14 803, 2001.

Robock, A.: Volcanic eruptions and climate, Rev. Geophys., 38, 2, 191-219, 2000.

Robock, A. and Mao, J.: Winter warming from large volcanic eruptions, Geophys. Res. Lett., 19, 2405-2408, 1992.

Seinfeld, J. H. and Pandis, S. N.: Atmospheric Chemistry and Physics: From Air Pollution to Climate Change, 958-996, Wiley, New York, 1998.

Spiro, P. A., Jacob, D. J., and Logan, J. A.: Global inventory of sulfur emissions with $1^{\circ} \times 1^{\circ}$ resolution, J. Geophys. Res., 97, 6023-6036, 1992.

Steingrimsson, J.: Fires of the Earth: the Laki eruption 1783-1784. Nordic Volcanological Institute and the University of Iceland Press, 1998.

Stevenson, D. S., Johnson, C. E., Collins, W. J., and Derwent, R. G.: Intercomparison and evaluation of atmospheric transport in a Lagrangian model (STOCHEM) and an Eulerian model (UM) using ${ }^{222} \mathrm{Rn}$ as a short-lived tracer, Q. J. R. Meteorol. Soc., 124, 2477-2491, 1998a.

Stevenson, D. S., Johnson, C. E., Collins, W. J., Derwent, R. G., Shine, K. P., and Edwards, J. M.: Evolution of tropospheric ozone radiative forcing, Geophys. Res. Lett., 25, 38193822, 1998b.

Stevenson, D. S., Highwood, E. J., Johnson, C. E., Collins, W. J., Derwent, R. G.: Atmospheric modelling of the 1783-1784 Laki eruption, UGAMP Newsletter, 24, 43-44, 2001.

Stevenson, D. S., Johnson, C. E., Collins, W. J., and Derwent, R.
G.: The tropospheric sulphur cycle and the role of volcanic $\mathrm{SO}_{2}$, In: Volcanic degassing: Experiments, Models, Observations and Impacts,(eds. Oppenhiemer, C., D. Pyle, and J. Barclay), Geol. Soc. Spec. Pub., in press, 2003.

Stothers, R. B.: The great dry fog of 1783, Climatic Change, 32, 79-89, 1996.

Stothers, R. B.: Far reach of the tenth century Eldgjá eruption, Climatic Change, 39, 715-726, 1998.

Thordarson, T. and Self, S.: Sulfur, chlorine, and fluorine degassing and atmospheric loading by the Roza eruption, Columbia River Basalt group, Washington, USA, J. Volcanol. Geotherm. Res., 74, 49-73, 1996.

Thordarson, T. and Self, S.: Atmospheric and environmental effects of the 1783-1784 Laki eruption; a review and reassessment, J. Geophys. Res., 108， D1， 4011， doi:10.1029/2001JD002042, 2003.

Thordarson, T., Self, S., Oskarsson, N., and Hulsebosch, T.: Sulfur, chlorine, and fluorine degassing and atmospheric loading by the 1783-1784 AD Laki (Skaftar Fires) eruption in Iceland, Bull. Volcanol., 58, 205-225, 1996.

Tie, X., Brasseur, G., Emmons, L., Horowitz, L., and Kinnison, D.: Effects of aerosols on tropospheric oxidants: A global model study, J. Geophys. Res., 106, 22 931-22 964, 2001.

Wallace, P. J.: Volcanic $\mathrm{SO}_{2}$ emissions and the abundance and distribution of exsolved gas in magma bodies, J. Volcanol. Geotherm. Res., 108, 85-106, 2001.

Wang, Y. and Jacob, D. J.: Anthropogenic forcing on tropospheric ozone and $\mathrm{OH}$ since preindustrial times, J. Geophys. Res., 103, 31 123-31 135, 1998.

Wesely, M. L., Cook, D. R., Hart, R. L. and Speer, R. E.: Measurements and parameterization of particulate sulphate dry deposition over grass, J. Geophys. Res., 90, 2131-2143, 1985.

Woods, A. W.: Moist convection and the injection of volcanic ash into the atmosphere, J. Geophys. Res., 98, 17 627-17 636, 1993.

Yienger, J. J. and Levy III, H.: An empirical model of global soilbiogenic $\mathrm{NO}_{\mathrm{x}}$ emission, J. Geophys. Res., 100, $11447-11464$, 1995.

Zielinski, G. A.: Stratospheric loading and optical depth estimates of explosive volcanism over the last 2100 years derived from the Greenland Ice Sheet Project 2 ice core, J. Geophys. Res., 100, 20937-20955, 1995. 